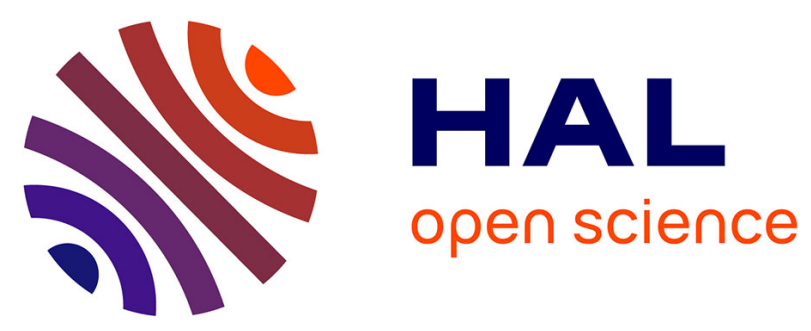

\title{
Distribution of the Habitat Suitability of the Main Malaria Vector in French Guiana Using Maximum Entropy Modeling
}

Yi Moua, Emmanuel Roux, Romain Girod, Isabelle Dusfour, Benoit de Thoisy, F. Seyler, Sébastien Briolant

\section{To cite this version:}

Yi Moua, Emmanuel Roux, Romain Girod, Isabelle Dusfour, Benoit de Thoisy, et al.. Distribution of the Habitat Suitability of the Main Malaria Vector in French Guiana Using Maximum Entropy Modeling. Journal of Medical Entomology, 2016, 10.1093/jme/tjw199 . hal-01425541

\section{HAL Id: hal-01425541 https://hal.science/hal-01425541}

Submitted on 6 Feb 2017

HAL is a multi-disciplinary open access archive for the deposit and dissemination of scientific research documents, whether they are published or not. The documents may come from teaching and research institutions in France or abroad, or from public or private research centers.
L'archive ouverte pluridisciplinaire HAL, est destinée au dépôt et à la diffusion de documents scientifiques de niveau recherche, publiés ou non, émanant des établissements d'enseignement et de recherche français ou étrangers, des laboratoires publics ou privés. 
Journal of Medical Entomology

Distribution of the habitat suitability of the main malaria vector in French Guiana using Maximum Entropy modeling

Yi Moua ${ }^{1}$, Emmanuel Roux ${ }^{2}$, Romain Girod ${ }^{3}$, Isabelle Dusfour ${ }^{3}$, Benoit de Thoisy ${ }^{4}$, Frédérique Seyler ${ }^{2}$, Sébastien Briolant ${ }^{3,5,6,7}$

${ }^{1}$ Université de Guyane, ESPACE-DEV, UMR 228 (IRD, UM, UR, UA, UG), Cayenne, French Guiana

${ }^{2}$ Institut de Recherche pour le Développement, ESPACE-DEV, UMR 228 (IRD, UM, UR, UA, UG), Montpellier, France

${ }^{3}$ Unité d'Entomologie Médicale, Institut Pasteur de la Guyane, Cayenne, French Guiana

${ }^{4}$ Laboratoire des Interactions Virus Hôtes, Institut Pasteur de la Guyane, Cayenne, French Guiana

${ }^{5}$ Direction Interarmées du Service de Santé en Guyane, Cayenne, French Guiana

${ }^{6}$ Institut de Recherche Biomédicales des Armées, Unité de Parasitologie et d'Entomologie

Médicale, Marseille, France

${ }^{7}$ Unité de Recherche en Maladies Infectieuses Tropicales Emergentes, UMR 63, CNRS 7278, IRD

198, INSERM 1095, Faculté de Médecine La Timone, Marseille, France 


\section{Abstract}

2 Malaria is an important health issue in French Guiana. Its principal mosquito vector in this region is

3 Anopheles darlingi. Knowledge of the spatial distribution of this species is still very incomplete due

4 to the extent of French Guiana and the difficulty to access most of the territory.

5 Species Distribution Modeling based on the maximal entropy procedure was used to predict the

$6 \quad$ spatial distribution of $A n$. darlingi using 39 presence sites.

7 The resulting model provided significantly high prediction performances (mean 10-fold cross-

8 validated partial AUC and continuous Boyce index equal to, respectively, 1.11 - with a level of

9 omission error of $20 \%$ - and 0.42 ). The model also provided a habitat suitability map and

10 environmental response curves in accordance with the known entomological situation.

11 Several environmental characteristics that had a positive correlation with the presence of $A n$.

12 darlingi were highlighted: non-permanent anthropogenic changes of the natural environment; the

13 presence of roads and tracks; opening of the forest. Some geomorphological landforms and high

14 altitude landscapes appear to be unsuitable for An. darlingi.

15 The Species Distribution Modeling was able to reliably predict the distribution of suitable habitats

16 for An. darlingi in French Guiana. Results allowed completion of the knowledge of the spatial

17 distribution of the principal malaria vector in this Amazonian region, and identification of the main

18 factors that favor its presence. They should contribute to the definition of a necessary targeted

19 vector control strategy in a malaria pre-elimination stage, and allow extrapolation of the acquired

20 knowledge to other Amazonian or malaria-endemic contexts.

21 Keywords: Maxent, species distribution model, presence-only, Anopheles darlingi, sampling bias 


\section{Moua et al. The habitat suitability of An. darlingi in French Guiana}

Malaria is a public health issue in the Amazonian region, with major transmission foci depending on specific local characteristics associated with changing environmental and socio-demographic contexts. French Guiana is a French overseas territory with $\sim 260,000$ inhabitants. It remains one of the major malaria foci in the region, despite an improving epidemiological situation during the past ten years. The number of reported clinical cases has significantly dropped from 4,479 in 2005 to 434 in 2015 (Petit-Sinturel et al. 2016), and now corresponds to an incidence rate of two cases for 1,000 inhabitants for the whole territory, making it possible to target the pre-elimination of the disease in 2018 (Agence Régionale de Santé Guyane 2015). Plasmodium vivax is at present predominant and this species was responsible for $67 \%$ of the diagnosed cases of malaria in the territory in 2014, the others being mainly due to Plasmodium falciparum (Musset et al. 2014, Ardillon et al. 2015). However, this epidemiological situation is heterogeneous in space and time. In particular, a recrudescence of malaria cases is currently observed in the inland region (Saül, Cacao, and Régina) and eastern French Guiana (municipalities of Camopi and Saint-Georges-del'Oyapock), with a general incidence rate reaching 55.2 cases per 1,000 inhabitants in 2013 (Musset et al. 2014), likely due to the emergence and/or persistence of local foci of high malaria transmission (Berger et al. 2012, Musset et al. 2014). This Amazonian region, especially near the international borders, includes vulnerable populations. Some are hard-to-reach and have poor access to health services and treatment-seeking behaviors that may favor the development of resistance to antimalarial drugs (Musset et al. 2014, Wangdi et al. 2015). Uncontrolled areas of malaria transmission are also prevalent in illegal gold mining areas (Pommier de Santi et al. 2016a, Pommier de Santi et al. 2016b). The epidemiological situation remains quite unstable, and preelimination of malaria, corresponding to an incidence rate below one case for 1,000 inhabitants in any locality of French Guiana, remains a major challenge.

In this context, public health authorities must maintain control efforts while targeting them more precisely and objectively in time and space (Alimi et al. 2015). A map of malaria risk in French 


\section{Moua et al. The habitat suitability of An. darlingi in French Guiana}

Guiana is updated regularly by the regional unit of the French National Public Health Agency, based on the number of cases reported per locality and the data available on movements of human populations at risk, especially due to gold mining activities. This map is validated by the local expert committee of epidemic diseases (Comité d'Experts des Maladies à Caractère Épidémique, CEMCE), which brings together different experts of the disease in the region (from the Health Surveillance Agency, the Pasteur Institute of French Guiana, the Regional Unit of the National Public Health Agency, vector control services, hospitals, and other diagnosis and care centers, and the Defense Health Service in French Guiana). The lack of objective knowledge of several key factors, especially the spatiotemporal distribution of the main malaria vectors and human populations infected by Plasmodium and/or carrying gametocytes, makes such a map highly approximate.

Anopheles (Nyssorhynchus) darlingi Root (Diptera: Culicidae) is one of the most efficient malaria vectors in South America and is considered to be the primary malaria vector in French Guiana because of its anthropophilic behavior, natural infectability, high density, and sensitivity to $P$. falciparum (Girod et al. 2008, Hiwat et al. 2010, Fouque et al. 2010). Used entomological data collection for the entire territory, for the mapping of entomological risk indicators at the regional scale, is not feasible. French Guiana occupies a large territory $\left(84,000 \mathrm{~km}^{2}\right)$ which is mostly covered by rain forest (more than $80 \%$ ) and highly inaccessible. Knowledge of the recent geographical distribution of An. darlingi is thus restricted to coastal areas, some villages along the international border rivers, and some illegal gold mining sites (Figure 1).

Species Distribution Modeling (SDM) offers an efficient solution to geographically extrapolate such knowledge to the entire territory (Pearson et al. 2007). Species Distribution Modeling produces maps of species habitat suitability by using known presence locations of the species and relevant environmental data. The use of SDM is thus encouraged to "improve and facilitate the development of alternative vector control strategies" (Alimi et al. 2015). Numerous SDM approaches are 


\section{Moua et al. The habitat suitability of An. darlingi in French Guiana}

proposed in the literature. Some of them, such as Maximum Entropy (Maxent; Phillips et al. 2006), Genetic Algorithm for Rule-Set Prediction (GARP; Stockwell 1999), Boosted Regression Trees (BRT; Friedman et al. 2000), Generalized linear and additive models (GLM and GAM; Guisan, et al. 2002), and Multivariate adaptive regression splines (MARS; Leathwick et al. 2005), exploit only species presence information, offering a significant advantage over methods that also require absence data. Indeed, absence data are often difficult to obtain. According to Peterson (2007) and Hirzel et al. (2002), absence can result from (1) the non-detection of the species in a suitable habitat, even if it is present, (2) the actual absence of the species for historical reasons, whereas the habitat is suitable, and (3) the true absence of the species and the unsuitability of the habitat. Comparative studies (Elith et al. 2006, Tognelli et al. 2009, Pearson et al. 2007, Hernandez et al. 2006, Wisz et al. 2008) show that Maxent is able to fit complex functions between habitat suitability and predictor variables, is the least sensitive to the size of the presence dataset, and tends to outperform other comparable methods when the dataset is small. In this study, the mapping of the habitat suitability of An. darlingi at the scale of all of French Guiana was performed using the Maxent SDM approach. This work aims to provide reliable maps for improving malaria transmission risk mapping in French Guiana, and to identify the environmental factors and associated mechanisms that favor the presence of An. darlingi.

\section{Materials and Methods}

\section{Study area}

French Guiana $\left(84,000 \mathrm{~km}^{2}\right)$, a French overseas region located in South America, is separated from Suriname by the Maroni River and from Brazil by the Oyapock River and the Tumuc-Humac mountains. More than $80 \%$ of the territory is covered by rain forest. The country has an equatorial climate characterized by two annual dry seasons, from mid-August to mid-November and in March, and two wet seasons, from mid-April to mid-August and mid-November to February. The average annual rainfall reaches $4,000 \mathrm{~mm}$ and 2,000 $\mathrm{mm}$ in the wettest (north-east) and driest (north-west) 


\section{Moua et al. The habitat suitability of An. darlingi in French Guiana}

areas, respectively (Hammond 2005). The average monthly rainfall is $>100 \mathrm{~mm}$ for the entire territory throughout the year, except for the three driest months: September, October, and November (Héritier, 2011). The average humidity is between $80 \%$ and $90 \%$. The temperature is homogeneous over the entire territory throughout the year, with an average annual temperature of $26^{\circ} \mathrm{C}$. The difference between the minimum and maximum daily temperature is more important than the annual variations. For example, in Maripasoula (on the border with Surinam) and Camopi (on the border with Brazil), the annual ranges of the minimum and maximum temperatures were, $4.3^{\circ} \mathrm{C}$ and $9.6^{\circ} \mathrm{C}$ (averages over the period 2001-2008), respectively, whereas the mean daily thermal amplitude was $9.8^{\circ} \mathrm{C}$ (average over the period 2001-2008; Météo-France, 2016). The population of $\sim 260,000$ inhabitants is unequally distributed throughout the territory. Approximately $90 \%$ of the population lives in the coastal area and most of the rest lives along the Maroni and the Oyapock rivers (Amerindians and Bush-Negroes). However many people live and/or transit through inland and remote areas of the territory (forestry workers, gold miners, and soldiers). According to many studies (Berger et al. 2012, Verret et al. 2006, Queyriaux et al. 2011, Hustache et al. 2007, Stefani et al. 2011, Pommier de Santi et al. 2016a), Amerindians, gold miners, and soldiers may be highly infected by malaria, whereas the areas in which they live and/or transit are those with the poorest knowledge of the presence and density of malaria vectors. It is thus of potential interest to consider the malaria risk, study the distribution of malaria vectors, and implement prevention and control actions over the entire territory of French Guiana.

\section{Species Records}

Presence sites of An. darlingi were provided by surveys of the Medical Entomology Unit of the Pasteur Institute of French Guiana and the Defense Health Service in French Guiana. Culicidae collections were performed using either human landing catches or traps (light traps or odor baited traps). Human landing catches consisted of exposing collector's lower leg and collecting landing mosquito with a mouth aspirator. Collectors were members of the Pasteur Institute or Defense 


\section{Moua et al. The habitat suitability of An. darlingi in French Guiana}

122 Health Services, they were aware of the risks associated with the method and had given their free 123 consent. Malaria prophylaxis was proposed and information on the medication was explained. Light 124 trap catches were performed with Center for Disease Control and Prevention (CDC) light traps, and 125 odor baited catches were performed with Mosquito Magnet ${ }^{\circledR}$ traps (Woodstream Corporation, Lititz, PA) baited with Octenol, a combination considered to be the best candidate for Anopheles surveillance in the region (Vezenegho et al., 2015).

Anopheles species were morphologically identified using taxonomic keys specific for the region (Floch and Abonnenc 1951, Faran and Linthicum 1981, Forattini 1962). Only Culicidae collections performed since the year 2000 were precisely geolocated by GPS coordinates and were used for the study (Figure 1). These data correspond to 74 capture sites for the family Culicidae, and to 48 presence sites for the species An. darlingi.

The difficulty in accessing most of the French Guiana territory, and the priority given to the areas at risk of malaria transmission where many people live, led to a significant sampling bias with oversampling of the anthropized region of the territory, notably those easily accessible by roads (Figure 1).

\section{Ecological knowledge and hypotheses}

The presence of An. darlingi is linked to compositional and configurational features of the land cover and land use, as they partially determine breeding, feeding, and resting sites of the vector

140 (Stefani et al. 2013). The natural environment for this vector in the Amazonian region includes floodable savanna, swamps (Girod et al. 2011, Zeilhofer et al. 2007), and flooded forest (Rozendaal 1992). Larvae are found along river edges, on flooded riverbanks, creeks, and pools formed near river-beds (Rozendaal 1992, Hiwat et al. 2010). Breeding sites are generally situated at low altitude

144 (Mouchet 2004) and solely in freshwater, as An. darlingi is sensitive to salinity (Deane et al. 1948). 


\section{Moua et al. The habitat suitability of An. darlingi in French Guiana}

147 Human activities, comprising deforestation and fish farming, also contribute to the creation of

148 active breeding sites (Patz et al. 2000, Richard 1987, Stefani et al. 2013, Takken et al. 2005,

149 Terrazas et al. 2015, Vittor et al. 2006, Vittor et al. 2009). Unpaved roads, tracks, and culverts form 150 ideal breeding sites for An. darlingi in the Amazon region (Singer and Castro 2001). The presence

151 of An. darlingi is also maintained by regular human presence due to its strong anthropophilic 152 behavior. However, the presence and density of An. darlingi can either be favored or restricted 153 depending on the type and intensity of the anthropogenic impacts. Stefani et al. (2013)

154 systematically reviewed the literature and showed that all the studies describe the same mechanisms 155 linking deforestation, land use, and the degree of urbanization with malaria transmission risk in the Amazonian region: opening the forest and maintaining a high degree of interaction between forested and deforested areas decreases the distance between feeding, breeding, and resting sites of An. darlingi, favoring the presence and high density of the vector (as well as a high probability of contact between humans and vectors); in contrast, intensifying deforestation and creating large urbanized and/or cultivated surfaces tends to decrease suitable habitat for An. darlingi. These two antagonistic consequences of human activities were considered in the SDM described here, by explicitly separating favorable and unfavorable factors in the environmental characterization. The optimum temperature range for $\mathrm{An}$. darlingi is between 20 and $30^{\circ} \mathrm{C}$ with a humidity of above $60 \%$ (Martens et al. 1995). Several studies established a minimal monthly rainfall threshold to designate suitable breeding habitats for Anopheles (reviewed in Smith et al. 2013). These values vary between 10 and $80 \mathrm{~mm}$ and need to be maintained for three or four months.

\section{Environmental Variables}

168 Environmental variables chosen as SDM inputs must characterize the ecological factors that 169 influence the presence of $A n$. darlingi, previously described. These factors are separated into three 170 types: 1) natural environment features, associated with land cover, land use, and geomorphology for 171 which the impact on the presence of An. darlingi depends on specific values or categorical classes; 


\section{Moua et al. The habitat suitability of An. darlingi in French Guiana}

172 2) anthropogenic activities that non-permanently alter the natural environment on a highly local

173 scale and favor the presence of An. darlingi; 3) urbanization, corresponding to human presence and 174 activities that permanently alter the natural environment over large areas and hinders the presence 175 of the vector. Meteorological variables were not included in the model, because the temperature, 176 rainfall, and humidity fall within the optimal ranges for presence of the species in French Guiana. 177 Thus, these variables cannot significantly explain differences in the time average habitat suitability 178 distribution over the year (this point is extensively discussed in the Discussion section).

179 Raw Geographic Data. Variables chosen as SDM inputs were derived from the following 180 raw geographic data:

$181-$ Geomorphological landscape $(G L S)$ and Geomorphological landforms $(G L F)$ from the 182 French Forest Office (ONF) (Guitet et al. 2013);

183 - Landscape types $(L S)$ from the French Agricultural Research Centre for International 184 Development (CIRAD) (Gond et al. 2011). This provides the distribution of landscape types 185 in French Guiana, most being forested landscapes;

- Altitude (ATL) derived from the Digital Elevation Model provided by the Shuttle Radar Topography Mission (SRTM, spatial resolution: 30 meters) of the United States Aeronautics and Space Administration (NASA);

- Human footprint (HFP): An integrated human activity index that gives a general measure of the extent of expected threats on biodiversity, by assigning a score depending on the nature of the disturbance. It combines sublayers spatializing human population density, urban areas, legal and illegal mining sites, agriculture, forest settlements and camps, tourist camps, logged areas (forest activities), and potential hunting areas corresponding to a zone of two kilometers around roads, tracks and rivers, likely to be used by humans. The total disturbance score is the sum of all human activity scores (de Thoisy et al. 2010); 


\section{Moua et al. The habitat suitability of An. darlingi in French Guiana}

and Forestry Information (IGN).

Table 1 summarizes the main features of these raw geographic data.

Definition of Environmental Variables Used as Inputs for SDM. Several variables were extracted from the previously described raw data to better reflect the ecological knowledge and hypotheses mentioned above. The reference spatial resolution (pixel size) permitting the integration of all environmental layers was set to 1 by $1 \mathrm{~km}$, i.e., the coarsest resolution of the available layers, associated with the $L S$ map.

The length of roads and tracks outside of urban areas $(R O A D S)$ was computed in the $1 \mathrm{~km}$-cell grid from the BD TOPO ${ }^{\circledR}$ database.

The sublayers composing the HFP were first rasterized into $30-\mathrm{m}$ grid cells, the smaller polygon of the $H F P$ having a size of approximately 40 by $10 \mathrm{~m}$. Distinct attributes were then extracted:

- The percentage of urbanization $\left(P E R \_U R B\right)$ within the $1 \mathrm{~km}$ grid cells;

- The percentage of urbanization within the eight neighbor cells of each urban cell (PER_URB_NEIGH), which permits distinguishing small from large urban areas. This layer was obtained for each $1 \mathrm{~km}$-cell considered to be urban (i.e., with PER_URB $\geq 50 \%$ ), by averaging the PER_URB values for the eight (1 km side) neighbor pixels;

- The human activities which non-permanently alter the natural environment $(H A)$, by first summing the scores of the following sublayers: tourist and forest camps, mining activities and logged areas, hunting areas nearby rivers, and then, by computing the minimum, median, and maximum values within the $1-\mathrm{km}$ grid cells.

The agriculture sublayer from $H F P$ was not used because it covers only the coastal area. The population density sublayer was also excluded because it did not have sufficient level of detail. The sublayer of potential hunting areas near roads and tracks were not used to avoid duplication of the length of roads and tracks outside of urban areas computed previously. For each 1-km grid cell, the majority class of the categorical variables $G L S$ and $G L F$, and the 


\section{Moua et al. The habitat suitability of An. darlingi in French Guiana}

222 minimum, median, and maximum altitude $(A L T)$ values were computed.

223 Eventually, some corrections of the $L S$ layer were performed as it did not identify urban areas and 224 did not distinguish flooded forests associated with freshwater from those of the coastal strip associated with brackish water (mangroves): $L S$ cells with an PER_URB value greater than or equal to $50 \%$ were reclassified into a new $L S$ class referred to as Urban; $L S$ cells classified as Flooded forest and corresponding to mangroves according to the coastal land use map provided by the ONF (Office National des Forêts Direction Régionale de Guyane, 2013) were reclassified as Mangrove. The variable PER_URB was excluded from the input SDM variables, as the urban areas were mapped, and their extent quantified, by the corrected $L S$ and PER_URB_NEIGH layers, respectively.

Table 1 lists and describes the environmental variables used to build the model.

\section{Maxent Model Principle}

234 Maxent is an SDM which requires environmental variables and species presence-only data. It is based on the principle of maximum entropy to estimate an (a priori) unknown probability distribution over the entire study area. This probability distribution assigns a value that is proportional to the probability of the presence of the species to each pixel of the study area. It is therefore interpreted as a habitat suitability index (HSI) across the study area (Phillips et al. 2006).

The Maximum Entropy principle consists of approximating the unknown probability distribution by 240 finding the one that maximizes entropy and satisfies the constraints imposed by the environmental

241 features at the known sites of presence. Environmental features are a set of input environmental variables chosen according to their expected relevance for the studied taxon (Phillips et al. 2006,

Elith et al. 2011). The constraints ensure that the environmental values expected under the 245 presence points. In practice, the Maxent distribution is defined on a set of points called background points. These 


\section{Moua et al. The habitat suitability of An. darlingi in French Guiana}

247 points should reflect the available environmental conditions of the study area and are chosen by

248 uniform random sampling. This approach assumes that the presence data are not biased and that

249 environmental conditions are uniformly sampled (Yackulic et al. 2013). However, in practice, some 250 areas are more intensively sampled than others, and environmental conditions are not uniformly 251 distributed and may imply a strong sampling bias. Phillips et al. (2009) proposed selecting the 252 background points with the same environmental bias as the presence dataset to correct the effect of 253 this sampling bias.

\section{Model Building and Evaluation}

255 Eleven environmental variables and $48 \mathrm{An}$. darlingi presence points (their coordinates were in the table in supplementary material S1) are used as inputs for Maxent. Only one presence site was selected to build the model when more than one occurred in the same pixel. As a result, only 39 presence sites were actually used for building the model. Hinge and categorical features were 259 selected for the environmental variables. A hinge feature provides a good compromise between 260 simplicity and the quality of the approximation of the species response curves (Elith et al. 2011, 261 Phillips and Dudík 2008).

262 In this study, the distribution of the background points was biased so that the selection bias 263 corresponds to that of the sampling. The sampling bias was defined as the relative sampling effort in 264 the environmental space, and was estimated by considering the capture locations of Culicidae, 265 obtained using the same capture techniques and supposed to be subjected to the same sampling bias as the An. darlingi species. The details of the method to create the relative sampling effort map are 267 described in supplementary material S2.

268 The model was computed using version 3.3.3k of Maxent. The recommended values derived from 269 Phillips and Dudík (2008) concerning the regularization parameters and the background set size, were applied. Regularization parameter values were set to 0.25 and 0.5 for categorical and hinge 271 features, respectively, and the size of the background was set to 10,000 . The extrapolation option 


\section{Moua et al. The habitat suitability of An. darlingi in French Guiana}

was not selected to avoid making predictions in environmental domains in which the model was not trained. The model was fitted using the full data set and evaluated using a 10-fold cross-validation procedure. The Receiver Operating Characteristic (ROC) curves and the associated Areas Under the ROC Curve (AUC) were computed. This was completed by computing the mean partial AUC ratios (Peterson et al., 2008), consisting of the ratios of the partial AUCs of the model over the null AUC (corresponding to random prediction), for omission errors $(E)$ of 20,10 , and $5 \%$. The Continuous Boyce Index (CBI), considered to better adapted to presence-only models than the AUC (Hirzel et al., 2006), was also computed. The gain (regularized training gain) was also used to evaluate the performance of the model prediction. It is a measure of the likelihood of the sample, and indicates how much better the estimated distribution fits the presence points than the uniform distribution, which corresponds to a null gain (Yost et al. 2008).

The importance of each variable was estimated using two methods, a heuristic method and the jackknife test. The heuristic method computes the percentage contribution of each variable to the model. During the training process, the increase of the gain is due to the adjustment of the feature weights and this increase is assigned to the environmental variable that the feature depends on. The sum of these increases in gain indicates the percentage contribution of each environmental variable. The jackknife test evaluates the individual contribution of each variable to the model by estimating the difference of the gain when removing each variable, one by one, and when considering the given variable alone to build the model.

\section{Results}

The mean AUC was 0.93, and the mean partial AUC ratios were 1.08, 1.03, and 1.01 for maximum omission errors sets to 20,10 , and $5 \%$ respectively. The mean CBI was 0.356 and the mean gain was 3.14 . Three variables cumulatively contributed $>80 \%$ (Table 2 ): the length of roads and tracks outside of urban areas $(R O A D S)$, the percentage of urbanization of neighboring pixels (PER_URB_NEIGH), and landscape $(L S)$. The maximum value of the human activities which non- 


\section{Moua et al. The habitat suitability of An. darlingi in French Guiana}

permanently alter the natural environment $\left(H A \_M A X\right)$, geomorphological landscape $(G L S)$, minimum altitude $\left(A L T \_M I N\right)$, and geomorphological landform $(G L F)$ contributed moderately to the model, with contributions of $6.84 \%, 5.35 \%, 1.34 \%$, and $1.19 \%$, respectively. The following input variables contributed very little to the model: minimum and median values of human activities which non-permanently alter the natural environment ( $H A \_M I N$ and $H A \_M E D ; 0.35$ and $0.24 \%$, respectively); and median and maximum values of altitude ( $A L T \_M E D$ and $A T L \_M A X ; 0.69$ and $0.06 \%$, respectively).

The results of the Jackknife test confirmed the non-significant contribution of the input variables HA_MIN, HA_MED, ALT_MED, and ALT_MAX (Table 2).

A second model was built using only the most highly contributing environmental variables: ROADS, LS, PER_URB_NEIGH, HA_MAX, GLS, GLF, and ALT_MIN. The overall performance of this simpler model was very similar to the previous one, with the mean AUC and partial AUC ratios equal to 0.93 and $1.11,1.05$, and 1.03 , respectively. The mean gain was equal to 3.19 and the mean CBI was 0.421 . Relative contributions of the input variables were also very similar (Table 3 ). The response curves of the environmental variables are represented in Figures 2 and 3. They show that the HSI is maximal when the PER_URB_NEIGH is below $8 \%$. Above this value, the HSI decreases progressively towards 0 . The HSI increases as $R O A D S$ increases up to 7,000 meters, reaches a plateau value, and then tends to decrease above 10,000 meters. Among all $L S$ classes, Woodland savanna/dry forest and Open forest contribute the most to the high HSI values. The geomorphological landscape classes Coastal flat plain and Plain with residual relief and the geomorphological landform classes Small-size and flat wet land, Small-size rounded hill, and Lowered half-orange relief - a tropical relief type corresponding to a hill with convex flanks giving to it a roughly hemispherical shape (George, 1972) and usually linked to flat or swampy lowlands drained by streams with meanders - are also associated with high HSI values. The HSI is maximal when $A L T$ is $\sim 0$, with a rapid decrease as altitudes increase. The $H A \_M A X$ response curve presents a 


\section{Moua et al. The habitat suitability of An. darlingi in French Guiana}

more complicated profile. The HSI increases for $H A \_M A X$ values between 0 and 8 , decreases until $H A \_M A X$ reaches 24, and then again increases as values continue to climb above 24 .

The map of habitat suitability for An. darlingi, based on all the presence data for modeling, shows six main areas $(A-F)$ with a high HSI and a seventh area $(G)$ corresponding to an epidemiological interest area (see Figure 4). A qualitative analysis was performed to determine the characteristics of the environmental variables of the areas with high HSI values (Table 4).

In the coastal area (A), where $90 \%$ of the Guyanese population lives, the HSI tends to be higher along the main road representing the main traffic route in French Guiana. Focusing on the main urban areas, represented in Figure 5, the HSI values within the highly urbanized districts of Cayenne and Kourou (rectangles in Figure 5) are lower than those of the surrounding pixels that are not considered to be highly urbanized. A very high HSI was predicted within the urban area of Saint-Laurent-du-Maroni. However, none of the pixels characterizing this city has a PER_URB_NEIGH value higher than or equal to $50 \%$. The high HSI values in areas $\mathrm{B}, \mathrm{D}, \mathrm{E}$, and $\mathrm{G}$ are characterized by the environmental variables $R O A D S, H A \_M A X$, the classes Open forest and Mixed high and open forest, and flat or moderately hilly terrain. The high HSI in areas C and F is essentially linked to Open forest and flat terrain.

The areas for which the model did not predict the HSI, due to the choice to not extrapolate to environmental domains not used to train the model, correspond to areas with an altitude higher than 400 meters. They represent a small number of pixels of the study area.

\section{Discussion}

The prediction performances of the model are excellent and significantly greater than those of the null model. The following discussion focuses on the ecological interpretation of the results and the methodological choices and alternatives.

\section{Environmental Factors Explaining the Habitat Suitability}

The geographic distribution of habitat suitability is consistent with existing knowledge of the 


\section{Moua et al. The habitat suitability of An. darlingi in French Guiana}

entomological situation despite the small number of presence points. The high HSI values can be explained by different environmental contexts depending on the geographical locations. In most areas (A, B, D, and E), the HSI values depend on human presence and activities, characterized by the environmental variables $H A \_M A X$ and $R O A D S$ (in areas $\mathrm{D}, \mathrm{E}$, and $\mathrm{B}$, most roads are not paved and correspond mostly to tracks). The significantly positive correlation between the variable ROADS and the HSI confirms that road and track opening, accompanied by deforestation and pooling of rainwater at the roadside, may favor breeding sites (Singer and Castro 2001). The response curve for the variable $R O A D S$ (Figure 3) reaches a plateau above 7,000 meters of road per square kilometer and decreases thereafter. The decrease of the HSI at values above 7,000 meters suggests that the density of the road network leads to an improvement of the road quality (paved road eliminating culverts, adding sidewalks), thus limiting the availability of breeding and/or resting sites, in the same way as urbanization. Indeed, the response curve of the PER_URB_NEIGH variable confirms that highly urbanized areas provide a poorly suitable habitat for An. darlingi (Figure 3). Intensive urbanization implies concrete paving, the decrease or removal of green areas and forests, and consequently, the destruction of breeding and resting sites for An. darlingi (Stefani et al. 2013). This phenomenon is observed in the highly urbanized areas of Cayenne and Kourou (Figure 5). In contrast, Saint-Laurent-du-Maroni, the second largest urban area of French Guiana in terms of urbanization size and density, has high HSI values. In fact, unlike Cayenne and Kourou, this area is not considered to be highly urbanized using the criterion of this study (PER_URB_NEIGH $\geq 50 \%$ ). However, the result for Saint-Laurent-du-Maroni seems unlikely because the presence of $A n$. darlingi has not yet been reported in an urban area. Further field works could confirm the presence of this species in the city. The sensitivity of the model for the criterion that defines a highly urbanized area may also merit further study.

The values of $H A \_M A X$ in areas $\mathrm{D}$ and $\mathrm{E}$ were essentially associated with mining activity. In French Guiana, this activity is responsible for forest loss reaching 2,000 hectares per year (Office National 
372 des Forêts Direction Régionale de Guyane, 2014). Between 2001 and 2013, Alvarez-Berríos and

373 Aide (2015) estimated that the largest forest loss due to gold mining in the tropical and subtropical

374 moist forest in South America was situated in the Guianan region including French Guiana. This

375 suggests that this activity, resulting in deforestation and creating sources of standing water such as

376 mining pits, combined with the presence of a large number of people, creates suitable conditions for

377 An. darlingi. The high HSI in these two areas is also explained by the Mixed high and open forest

378 landscape which is associated with human disturbance (Gond et al. 2011). Indeed, this landscape is

379 described as a forest environment linked to young or unstable vegetation mostly due to first stages

380 of anthropization. These results confirm the important role of human presence in the creation of

381 suitable habitats for An. darlingi, which is also consistent with the strong anthropophilic behavior of

382 this vector.

383 Some landscape types which are not directly associated with human presence or activities were also

384 associated with a HSI. The Woodland savanna/dry forest class appears to highly contribute to high

385 HSI values (Figure 2). It corresponds to the driest landscape in French Guiana (Gond et al. 2011),

386 but can be seasonally inundated due to its poor drainage, creating breeding sites (Rosa-Freitas et al.

387 2007). The high HSI values in this area are in accordance with previous studies (Vezenegho et al.

388 2015, Dusfour et al. 2013), which reported finding An. darlingi in the coastal savanna environments

389 of French Guiana. In uninhabited areas (zones F and C in Figure 4), a high HSI is associated with

390 the Open forest class (LS layer) and flat terrain. This LS class can be associated with different land

391 cover types in French Guiana (Gond et al. 2011) depending on the geographical location.

392 Consequently, this $L S$ class may differentially affect An. darlingi habitat suitability. The Open forest 393 in area C mainly corresponds to wetlands (classified as Flooded forest according to the coastal land 394 use map provided by the Office National des Forêts Direction Régionale de Guyane, 2013), whereas 395 in area F, it corresponds to Large surfaces of bamboo thicket and forbs. Anopheles darlingi was 396 found in flooded forest; however, to our knowledge, no information is available concerning its 


\section{Moua et al. The habitat suitability of An. darlingi in French Guiana}

presence in large areas of bamboo thicket and forbs. The prediction in these areas should be taken with precaution as a more precise description of the habitats within Open forest class is required. Overall, this information highlights that natural environment could form highly suitable habitats despite the high anthropophily of An. darlingi.

\section{Meteorological Variables}

In this study, meteorological variables were not used to build the model. Temperatures fall within the optimal range for the species presence, and were considered to be geographically and temporally too homogeneous to explain differences in the spatial distribution of habitat suitability. Such a hypothesis is common in the Amazonian context. Olson et al. (2009) report that in their study region (Amazon basin), "monthly temperatures were between $24.6^{\circ} \mathrm{C}$ and $29.4^{\circ} \mathrm{C}$ (well within the range for optimal malaria transmission) for 95\% of the observations," and consequently did not include temperatures in their model. In French Guiana, several studies also used rainfall data to study the intra-annual variations in An. darlingi density (Hiwat et al., 2010, Girod et al., 2011). The exclusion of rainfall data is more debatable, as rainfall clearly influenced the intra-annual density of An. darlingi in the study region (Hiwat et al., 2010, Girod et al., 2011, Vezenegho et al., 2015) even if the relationship was not systematically observed (Girod et al., 2011). The evidence for this impact on densities is that $A n$. darlingi habitat suitability varies at an intra-annual scale, due to the alternation of dry and wet seasons. However, the entire study area is subject to this alternation. Moreover, given the high density of the French Guiana hydrological network and that the driest area (north-west) still receives 2,000 $\mathrm{mm}$ a year, it can be reasonably assumed that An. darlingi can find suitable conditions within the entire territory throughout most of the year. In French Guiana, the geomorphological landscape highly influences the availability of breeding sites, and therefore their spatial distribution, whereas the rainfall quantities influence the intra-annual variations of $A n$. darlingi densities. As a consequence, on an average over the year, we assume that the significant factor influencing the distribution of habitat suitability is not the quantity of rainfall, but the 


\section{Moua et al. The habitat suitability of An. darlingi in French Guiana}

422 capacity of the landscape to provide suitable breeding sites when it rains.

\section{Model Parametrization}

424 The model was run by using the regularization parameter values and background set size recommended by Phillips and Dudík (2008), instead of those determined from specific experiments, as suggested by Merow et al. (2013). Phillips and Dudík (2008) tested a set of regularization parameter values with 48 species datasets that contained 11 to 13 environmental variables and a small number of categorical variables (1-3, as they considered discrete ordinal variables to be categorical). Nine of these datasets contained between 30 and 60 occurrences. The characteristics of the dataset exploited in our study (39 occurrence records; 13 and seven environmental variables including three categorical ones) are assumed to be quite similar of those of the datasets used by Phillips and Dudík (2008). We thus assumed that the pseudo-optimal parameters proposed by Phillips and Dudík (2008) could be confidently used in our study. Similarly, the background size was set to 10,000 based on the tests realized by Phillips and Dudík (2008), with 226 species and a median number of 57 presence sites. Better prediction performance may have been obtained by tuning the regularization values and background size and adding input environmental variables and features. However, the risk would have been to favor overfitting to the detriment of the bioecological interpretation of the model (see for example Merow et al., 2013). According to the

439 entomologists who participated in the study, the model appears to be a good compromise between overfitting (that would have predicted suitable areas near occurrence points only) and being too

441 general (that would have predicted suitable areas in too many environmental contexts for which the 442 specialists have no species presence evidence).

\section{Correction of the sampling bias effect}

444 In this study, the effect of sampling bias was corrected by selecting background points with the 445 same environmental bias as the sampled points. This approach appeared to be useful when applied to An. darlingi in French Guiana. Without a bias effect correction, the model predicted very high 


\section{Moua et al. The habitat suitability of An. darlingi in French Guiana}

HSI values in highly urbanized areas whereas these areas are known to be unsuitable for this vector

(see above). The biased background set is more concentrated around the sampled points (in the environmental space) than the uniform random background, and is not likely to include environmental conditions that are highly dissimilar to those encountered at the sampled points. As a result, environmental conditions highly dissimilar to those of the sampled points can be subjected to extrapolation, which may lead to erroneous habitat suitability predictions and bio-ecological interpretations. This justifies not using the extrapolation option for modeling. The predicted HSI map from the model with a biased background contains several excluded areas, whereas that of the model with a uniform random background does not. Excluded areas correspond to high altitude areas which are unsuitable for An. darlingi (Mouchet 2004).

When using a uniform random background, the three most contributive variables (cumulative contribution equal to $85.5 \%$ ) were all directly linked to human presence and territory accessibility (ROADS: 38.1\%, PER_URB_NEIGH: 34.9\%, and HA_MAX: 12.5\%). Thus, apart from urban areas, high HSI values were associated with high $H A \_M A X$ and $R O A D S$ values. However, when correcting the sampling bias effect, the Landscape $(L S)$ variable was the second most contributive variable (14.1\%), the ROADS variable contribution increased to $62.6 \%$, and the PER_URB_NEIGH variable contribution decreased to $11.1 \%$ (see Table 3).

From a quantitative point of view, the two approaches (with and without applying the correction of the sampling bias effect) resulted in identical AUC and partial AUC ratios. However, the regularized gain and the CBI were lower without correction, with values equal to 2.81 (vs. 3.18) and 0.284 (vs. $0.421)$, respectively.

Thus, correction of the sampling bias effect gave better results: both more consistent with knowledge from the field and more accurate in terms of prediction. The fact that the contributions of the $L S$ and $H A \_M A X$ variables respectively increased and decreased with the use of the biased background, tends to show that the correction method actually manages to counterbalance the over- 


\section{Moua et al. The habitat suitability of An. darlingi in French Guiana}

472 representation of inhabited areas (cities, villages, and gold mining areas) in the sampled data.

473 However, the very high contribution of the variable ROADS may be a residual effect of sampling

474 bias, as sampling is essentially performed in the vicinity of accessible roads and tracks. Further studies are necessary to objectively and quantitatively assess the actual performance of the proposed methodology for correcting the effect of sampling bias.

\section{Habitat Suitability and Malaria in French Guiana}

Alimi et al. (2015) highlighted the utility of SDMs for gaining a better understanding of the geographical range and distribution of vectors for eliminating malaria and preventing outbreaks. The coastal strip in French Guiana is generally malaria free, although some cases resulting from local transmission are regularly diagnosed (Ardillon et al. 2015). This study, as well as that of Vezenegho et al. (2015), shows that the savanna in French Guiana may be highly suitable for An. darlingi. In the forest, Pommier de Santi et al. (2016c) found a link between mining, malaria cases, and the presence of $A n$. darlingi. Indeed, $>74 \%$ of malaria cases in French army soldiers were associated with operations to counteract illegal gold mining (Pommier de Santi et al. 2016a). According to the results of the present study, some areas associated with intense gold mining activity, known to be malaria transmission foci, are not necessarily associated with very high HSI values. In the village of Camopi, the annual malaria prevalence was $70 \%$ for children younger than seven years of age between 2000 and 2002 (Carme et al. 2005), reaching 100\% in 2006 (Hustache et al. 2007). However, only some pixels on the border of the Camopi and Oyapock rivers have high values on the HSI map (area G in Figure 4). This is consistent with the study of Girod et al. (2011), which showed that the number of $A n$. darlingi caught in this village was very low relative to the incidence of malaria cases. These findings collectively highlight two important points. First, the HSI map shown in Figure 4 does not correspond to a map of malaria transmission risk. Transmission risk depends on many factors that were not taken into account here, such as the parasitic charge and immunological status of the local population, compositional and 


\section{Moua et al. The habitat suitability of An. darlingi in French Guiana}

configurational features of the landscape (Stefani et al, 2013; Li et al, 2016), and behavioral factors.

Second, this highlights that malaria transmission can occur in areas where there is a very low density of An. darlingi. This may be due to the presence of other Anopheles species such as An. (Nys.) nuneztovari Galbaldón, An. (Nys.) oswaldoi Peryassú, An. (Nys.) intermedius Peryassú, An. (Nys.) marajoara Galvão and Damasceno, or An. (Nys.) ininii Sénevet and Abonnenc (Diptera: Culicidae), already known to be naturally infected with Plasmodium species and/or described as efficient secondary malaria vectors (Dusfour et al. 2012, Pommier de Santi et al, 2016c).

\section{Environmental Characterization}

A significant limitation of this study was the spatial resolution of the environmental data. Capture campaigns are generally carried out at a local scale (villages or camps; Vezenegho et al. 2015,

Dusfour et al. 2013). The spatial resolution of the study was not sufficient to take into account the heterogeneity of the environment at the capture scale. The use of environmental data with higher spatial resolution, such as the canopy height estimation from Fayad et al. (2014) or finer characterization of the land cover could improve future studies. However, these data are not consistently available across the entire territory.

In conclusion, the results of this study help to complete our knowledge on the spatial distribution of the principal malaria vector in this Amazonian region, and to identify the main factors that favor its presence. These results can be exploited to define the necessary targeted vector control strategies in a malaria pre-elimination context, and to extrapolate the acquired knowledge to other Amazonian contexts. They also suggest areas that need to be targeted to complete the field knowledge, validate the prediction and strengthen the model. Eventually, these proposed methodological developments can be applied to other species, including other disease vectors.

521 This study was funded by the Fonds Social Européen (FSE), Centre National d'Etudes Spatiales 


\section{Moua et al. The habitat suitability of An. darlingi in French Guiana}

522 (CNES), and Collectivité Territoriale de Guyane. Financial support was partially provided by the

523 "Investissement d'Avenir" grants managed by the Agence Nationale de la Recherche (Center for the 524 study of Biodiversity in Amazonia, ANR-10-LABX-0025) and by the GAPAM-Sentinela project of 525 the Franco-brazilian scientific and academic cooperation program Guyamazon (funds: IRD,

526 CIRAD, French Embassy in Brazil, Territorial Collectivity of French Guiana, Brazilian State-level 527 research agencies of Amapá, Amazonas and Maranhão).

References cited

529 Agence Régionale de Santé Guyane. 2015. Plan de lutte contre le paludisme en Guyane 2015530 2018. Agence Régionale de Santé Guyane, Cayenne, France.

Alimi, T.O., D. O. Fuller, M. L. Quinones, R-D. Xue, S. V. Herrera, M. Arevalo-Herrera, J. N. Ulrich, W. A. Qualls, and J. C. Beier. 2015. Prospects and recommendations for risk mapping to improve strategies for effective malaria vector control interventions in Latin America. Malar. J. 14:519.

Alvarez-Berríos, N. L., and T. M. Aide. 2015. Corrigendum: Global demand for gold is another threat for tropical forests (2014 Environ. Res. Lett. 10: 014006). Environ. Res. Lett. 10: 29501.

Ardillon, V., L. Carvalho, C. Prince, P. Abboud, and F. Djossou. 2015. Bilans 2013 et 2014 de la situation du paludisme en Guyane. Bulletin de Veille Sanitaire Antilles-Guyane. 1: 16-20.

Berger, F., C. Flamand, L. Musset, F. Djossou, J. Rosine, M.-A. Sanquer, I. Dusfour, E. Legrand, V. Ardillon, P. Rabarison, C. Grenier and R. Girod. 2012. Investigation of a sudden malaria outbreak in the isolated Amazonian village of Saul, French Guiana, January-April 2009. Am. J. Trop. Med. Hyg. 86: 591-597.

Carme, B., J. Lecat, and P. Lefebvre. 2005. [Malaria in an outbreak zone in Oyapock (French Guiana): incidence of malaria attacks in the American Indian population of Camopi] (in French) Médecine tropicale 65: 149-154.

Deane, L. M., O. R. Causey, and M. P. Deane. 1948. Notas sobre a distribuição ea biologia dos 


\section{Moua et al. The habitat suitability of An. darlingi in French Guiana}

anofelinos das regiões nordestina e Amazônica do Brasil. Revista do Serviço Especial de Saúde Pública 1: 827-965.

de Thoisy, B., C. Richard-Hansen, B. Goguillon, P. Joubert, J. Obstancias, P. Winterton, and S. Brosse. 2010. Rapid evaluation of threats to biodiversity: human footprint score and large vertebrate species responses in French Guiana. Biodivers. Conserv. 19: 1567-84.

Dusfour, I., J. Issaly, R. Carinci, P. Gaborit, and R. Girod. 2012. Incrimination of Anopheles (Anopheles) intermedius Peryassú, An. (Nyssorhynchus) nuneztovari Gabaldón, An. (Nys.) oswaldoi Peryassú as natural vectors of Plasmodium falciparum in French Guiana. Memórias Do Instituto Oswaldo Cruz 107: 429-432.

Dusfour, I., R. Carinci, J. Issaly, P. Gaborit, and R. Girod. 2013. A survey of adult Anophelines in French Guiana: enhanced descriptions of species distribution and biting responses. J. Vector Ecol. 38: 203-209.

Elith, J., C. H. Graham, R. P Anderson, M. Dudik, S. Ferrier, A. Guisan, R. J. Hijmans, F. Huettmann, J. R. Leathwick, A. Lehmann, et al. 2006. Novel methods improve prediction of species' distributions from occurrence data. Ecography 29: 129-151.

Elith, J., S. J. Phillips, T. Hastie, M. Dudík, Y. E. Chee, and C. J. Yates. 2011. A statistical explanation of MaxEnt for ecologists: statistical explanation of MaxEnt. Divers. Distrib. 17: 4357.

Faran, M. E., and K. J. Linthicum. 1981. A handbook of the Amazonian species of Anopheles (Nyssorhynchus) (Diptera: Culicidae). Mosq. Syst. 13: 1-81

Fayad, I., N. Baghdadi, J-S. Bailly, N. Barbier, V. Gond, M. Hajj, F. Fabre, and B. Bourgine. 2014. Canopy height estimation in French Guiana with LiDAR ICESat/GLAS data using principal component analysis and Random Forest regressions. Rem. Sens. 6: 11883-11914.

Floch, H., and E. Abonnenc. 1951. Anophèles de la Guyane française. Archives de l'Institut Pasteur de la Guyane et du territoire de l'Inini. 236:1-92 
Moua et al. The habitat suitability of An. darlingi in French Guiana

572 Forattini, O. P. 1962. Entomologia Médica : Vol. 1. Parte Geral, Diptera, Anophelini. Faculdade de 573 Higiene e Saúde Pública, Departamento de Parasitologia, Universidade de São Paulo, São Paulo, 574 Brazil.

575 Fouque, F., P. Gaborit, R. Carinci, J. Issaly, and R. Girod. 2010. Annual variations in the 576 number of malaria cases related to two different patterns of Anopheles darlingi transmission 577 potential in the Maroni area of French Guiana. Malar. J. 9: 80.

578 Friedman, J., T. Hastie, and R. Tibshirani. 2000. Additive Logistic Regression: a Statistical View 579 of Boosting. Ann. Stat. 28: 337-407.

580 George, P. 1972. Dictionnaire de la géographie. Presse Universitaire de France, Paris, France.

581 Girod, R., P. Gaborit, R. Carinci, J. Issaly, and F. Fouque. 2008. Anopheles darlingi bionomics 582 and transmission of Plasmodium falciparum, Plasmodium vivax and Plasmodium malariae in 583 Amerindian villages of the Upper-Maroni Amazonian forest, French Guiana. Memórias Do $584 \quad$ Instituto Oswaldo Cruz 103: 702-710.

585 Girod, R., E. Roux, F. Berger, A. Stefani, P. Gaborit, R. Carinci, J. Issaly, B. Carme, and I. 586 Dusfour. 2011. Unravelling the relationships between Anopheles darlingi (Diptera: Culicidae) 587 densities, environmental factors and malaria incidence: understanding the variable patterns of 588 malarial transmission in French Guiana (South America). Ann. Trop. Med. Parasitol. 105: 107$589 \quad 122$.

590 Gond, V., V. Freycon, J-F. Molino, O. Brunaux, F. Ingrassia, P. Joubert, J-F. Pekel, M-F. 591 Prévost, V. Thierron, P-J. Trombe, and D. Sabatier. 2011. Broad-scale spatial pattern of forest 592 landscape types in the Guiana Shield. Int. J. Appl. Earth Obs. Geoinf. 13: 357-367.

593 Guisan, A., T. C. Edwards, and T. Hastie. 2002. Generalized linear and generalized additive 594 models in studies of species distributions: setting the scene. Ecol. Model. 157: 89-100.

595 Guitet, S., J-F. Cornu, O. Brunaux, J. Betbeder, J-M. Carozza, and C. Richard-Hansen. 2013. 596 Landform and landscape mapping, French Guiana (South America). J. Maps. 9: 325-35. 


\section{Moua et al. The habitat suitability of An. darlingi in French Guiana}

Hammond, D. S. 2005. Tropical forests of the Guiana Shield: ancient forests in a modern world. CABI publishing, Wallingford, England.

Héritier, P. 2011. Le climat guyanais ; petit atlas climatique de la Guyane française. Météo France, Cayenne, France.

Hernandez, P. A., C. H. Graham, L. L. Master, and D. L. Albert. 2006. The effect of sample size and species characteristics on performance of different species distribution modeling methods. Ecography 29: 773-785. Hirzel, A. H., J. Hausser, D. Chessel, and N. Perrin. 2002. Ecological-niche factor analysis: how to compute habitat-suitability maps without absence data? Ecology 83: 2027-2036.

Hirzel, A. H., G. Le Lay, V. Helfer, C. Randin, and A. Guisan. 2006. Evaluating the ability of habitat suitability models to predict species presences. Ecol. Model. 199: 142-152.

Hiwat, H., J. Issaly, P. Gaborit, A. Somai, A. Samjhawan, P. Sardjoe, T. Soekhoe, and R. Girod. 2010. Behavioral heterogeneity of Anopheles darlingi (Diptera: Culicidae) and malaria transmission dynamics along the Maroni River, Suriname, French Guiana. Trans. R. Soc. Trop. Med. Hyg. 104: 207-213.

Hustache, S., M. Nacher, F. Djossou, and B. Carme. 2007. Malaria risk factors in Amerindian children in French Guiana. Am. J. Trop. Med. Hyg. 76: 619-625.

Leathwick, J. R., D. Rowe, J. Richardson, J. Elith, and T. Hastie. 2005. Using multivariate adaptive regression splines to predict the distributions of New Zealand's freshwater diadromous fish. Freshw. Biol. 50: 2034-2052.

Li, Z., E. Roux, N. Dessay, R. Girod, A. Stefani, M. Nacher, A. Moiret, and F. Seyler. 2016. Mapping a knowledge-based malaria hazard index related to landscape using remote sensing: application to the cross-border area between French Guiana and Brazil. Remote Sens. 8: 1-22.

Martens, W. J., L. W. Niessen, J. Rotmans, T. H. Jetten, and A. J. McMichael. 1995. Potential impact of global climate change on malaria risk. Environ. Health Perspect. 103: 458-64. 


\section{Moua et al. The habitat suitability of An. darlingi in French Guiana}

Météo-France. 2016. Données pluviométriques disponibles au 01/01/2016 (http://pluiesextremes.meteo.fr/guyane/IMG/sipex_pdf/carte_reseau dep973.pdf). Last accessed the 7 Oct. 2016.

Merow, C., M. J. Smith, and J. A. Silander. 2013. A Practical guide to MaxEnt for modeling species' distributions: what it does, and why inputs and settings matter. Ecography 36: 10581069.

\section{Musset, L., S. Pelleau, R. Girod, V. Ardillon, L. Carvalho, I. Dusfour, M. SM Gomes, F.} Djossou, and E. Legrand. 2014. Malaria on the Guiana Shield: a review of the situation in French Guiana. Memórias Do Instituto Oswaldo Cruz 109: 525-33.

Mouchet, J. 2004. Biodiversité du paludisme dans le monde. John Libbey Eurotext, Montrouge, France

Office National des Forêts Direction Régionale de Guyane. 2013. PROJET “EXPERTISE LITTORAL 2011" Occupation du sol et sa dynamique sur la bande côtière de la Guyane de 2005 à 2011. Office National des Forêts et le Ministère de l'Agriculture, de l'Agroalimentaire et de la Forêt, Cayenne, France.

Office National des Forêts Direction Régionale de Guyane. 2014. Rapport d'activité 2013. Office National des Forêts et le Ministère de l'Agriculture, de l'Agroalimentaire et de la Forêt, Cayenne, France.

Olson, S. H., R. Gangnon, E. Elguero, L. Durieux, J. F. Guégan, J. A. Foley, and J. A. Patz. 2009. Links between climate, malaria, and wetlands in the Amazon Basin. Emerg. Infect. Dis.15: $659-662$

Patz, J. A., T. K. Graczyk, N. Geller, and A. Y. Vittor. 2000. Effects of environmental change on emerging parasitic diseases. Int. J. Parasitol. 30: 1395-1405.

Pearson, R. G., C. J. Raxworthy, M. Nakamura, and A. Townsend Peterson. 2007. Predicting species distributions from small numbers of occurrence records: a test case using cryptic geckos 


\section{Moua et al. The habitat suitability of An. darlingi in French Guiana}

in Madagascar: Predicting species distributions with low sample sizes. J. Biogeogr. 34: 102-117.

Peterson, A. T. 2007. Ecological niche modelling and understanding the geography of disease transmission. Vet. Ital. 43: 393-400.

Peterson, A. T., M. Papeş, and J. Soberón. 2008. Rethinking receiver operating characteristic analysis applications in ecological niche modeling. Ecol. Model. 213: 63-72.

Petit-Sinturel, M., L. Carvalho, A. Andrieu, C. Prince, P. Abboud, F. Djossou, and V. Ardillon. 2016. Situation du paludisme en Guyane française en 2015. Bulletin de Veille Sanitaire AntillesGuyane. 2: 6-10.

Phillips, S. J., R. P. Anderson, and R. E. Schapire. 2006. Maximum entropy modeling of species geographic distributions. Ecol. Model. 190: 231-259.

Phillips, S. J., and M. Dudík. 2008. Modeling of species distributions with Maxent: new extensions and a comprehensive evaluation. Ecography 31: 161-175.

Phillips, S. J., M. Dudík, J. Elith, C. H. Graham, A. Lehmann, J. Leathwick, and S. Ferrier. 2009. Sample selection bias and presence-only distribution models: implications for background and pseudo-absence data. Ecol. Appl. 19: 181-197.

Pommier de Santi, V., A. Dia, A. Adde, G. Hyvert, J. Galant, M. Mazevet, C. Nguyen, S. B. Vezenegho, I. Dusfour, R. Girod, and S. Briolant. 2016a. Malaria in French Guiana Linked to Illegal Gold Mining. Emerging Infect. Dis. 22: 344-346.

Pommier de Santi, V., F. Djossou, N. Barthes, H. Bogreau, G. Hyvert, C. Nguyen, S. Pelleau, E. Legrand, L. Musset, M. Nacher, and S. Briolant. 2016b. Malaria hyperendemicity and risk for Artemisinin resistance among illegal gold miners, French Guiana. Emerging Infect. Dis. 22: 903-906

Pommier de Santi, V., R. Girod, M. Mura, A. Dia, S. Briolant, F. Djossou, I. Dusfour, A. Mendebil, F. Simon, X. Deparis, and F. Pagès. 2016c. Epidemiological and entomological studies of a malaria outbreak among French armed forces deployed at illegal gold mining sites 


\section{Moua et al. The habitat suitability of An. darlingi in French Guiana}

reveal new aspects of the disease's transmission in French Guiana. Malar. J. 15: 35.

Queyriaux, B., G. Texier, L. Ollivier, L. Galoisy-Guibal, R. Michel, and J. B. Meynard. 2011. Plasmodium vivax malaria among military personnel, French Guiana, 1998-2008. Emerging Infect. Dis. $17: 1280-1282$.

Richard, A. 1987. Le Paludisme en forêt, pp. 249-250. In Connaissance Du Milieu Amazonien, 1516 October 1985, Paris, France. ORSTOM, Paris, France. Rosa-Freitas, M. G., P. Tsouris, A. T. Peterson, N. A. Honório, F. S. M. de Barros, D. B. de Aguiar, H. C. Gurgel, M. de Arruda, S. D. Vasconcelos, and J. F. Luitgards-Moura. 2007. An ecoregional classification for the state of Roraima, Brazil. The importance of landscape in malaria biology. Memórias Do Instituto Oswaldo Cruz. 102: 349-358.

Rozendaal, J. A. 1992. Relations between Anopheles darlingi breeding habitats, rainfall, river level and malaria transmission rates in the rain forest of Suriname. Med. Vet. Entomol. 6: 16-22.

Singer, B. H., and M. C. Castro. 2001. Agricultural colonization and malaria on the Amazon frontier. Ann. N. Y. Acad. Sci. 954: 184-222.

Smith, M. W., M. G. Macklin, and C. J. Thomas. 2013. Hydrological and geomorphological controls of malaria transmission. Earth-Sci. Rev. 116: 109-127.

Stefani, A., E. Roux, J. M. Fotsing, and B. Carme. 2011. Studying relationships between environment and malaria incidence in Camopi (French Guiana) through the objective selection of buffer-based landscape characterizations. Int. J. Health Geogr. 10: 1-13.

Stefani, A., I. Dusfour, A. P. S. A. Corrêa, M. C. B. Cruz, N. Dessay, A. K. R. Galardo, C. D. Galardo, R. Girod, M. S. M. Gomes, and H. Gurgel. 2013. Land cover, land use and malaria in the Amazon: a systematic literature review of studies using remotely sensed data. Malar. J. 12: $1-8$.

Stockwell, D. 1999. The GARP modelling system: problems and solutions to automated spatial prediction. Int. J. Geogr. Inf. Sci. 13: 143-158. 
Moua et al. The habitat suitability of An. darlingi in French Guiana

Takken, W., P. D. R. Vilarinhos, P. Schneider, and F. Dos Santos. 2005. Effects of environmental change on malaria in the Amazon region of Brazil. Frontis 9: 113-123.

Terrazas, W., V. Sampaio, D. de Castro, R. C. Pinto, B. C. de Albuquerque, M. Sadahiro, R. dos Passos, and J. U. Braga. 2015. Deforestation, drainage network, indigenous status, and geographical differences of malaria in the state of Amazonas. Malar. J. 14: 379.

Tognelli, M. F., S. A. Roig-Juñent, A. E. Marvaldi, G. E. Flores, and J. M. Lobo. 2009. An evaluation of methods for modelling distribution of Patagonian insects. Revista Chilena de Historia Natural 82: 347-360.

Verret, C., B. Cabianca, R. Haus-Cheymol, J-J. Lafille, G. Loran-Haranqui, and A. Spiegel. 2006. Malaria outbreak in troops returning from French Guiana. Emerg. Infect. Dis. 12: 17941795.

Vezenegho S.B., R. Carinci, P. Gaborit, J. Issaly, I. Dusfour, S. Briolant and R. Girod. 2015. Anopheles darlingi (Diptera: Culicidae) dynamics in relation to meteorological data in a cattle farm located in the coastal region of French Guiana: advantage of Mosquito Magnet trap. Environ. Entomol. 44: 454-462.

Vittor, A. Y., R. H. Gilman, J. Tielsch, G. Glass, T. I. M. Shields, W. Lozano, V. PinedoCancino, and J. A. Patz. 2006. The effect of deforestation on the human-biting rate of Anopheles darlingi, the primary vector of falciparum malaria in the Peruvian Amazon. Am. J. Trop. Med. Hyg. 74: 3-11.

Vittor, A. Y., W. Pan, R. H. Gilman, J. Tielsch, G. Glass, T. Shields, W. Sánchez-Lozano, V. V. Pinedo, E. Salas-Cobos, and S. Flores. 2009. Linking deforestation to malaria in the Amazon: characterization of the breeding habitat of the principal malaria vector, Anopheles darlingi. Am. J. Trop. Med. Hyg. 81: 5-12.

Wangdi, K., M. L. Gatton, G. C. Kelly, and A. C. A. Clements. 2015. Cross-Border Malaria: A Major Obstacle for Malaria Elimination. Adv. Parasitol., 89:79-107. 


\section{Moua et al. The habitat suitability of An. darlingi in French Guiana}

722 Wisz, M. S., R. J. Hijmans, J. Li, A. T. Peterson, C. H. Graham, A. Guisan, and NCEAS

723 Predicting Species Distributions Working Group. 2008. Effects of sample size on the

724 performance of species distribution models. Divers. Distrib. 14: 763-773.

725 Yackulic, C. B., R. Chandler, E. F. Zipkin, J. A. Royle, J. D. Nichols, E. H. Campbell Grant,

726 and S. Veran. 2013. Presence-only modelling using MAXENT: when can we trust the

727 inferences? Methods Ecol. Evol. 4: 236-243.

728 Yost, A. C., S. L. Petersen, M. Gregg, and R. Miller. 2008. Predictive modeling and mapping

729 sage grouse (Centrocercus Urophasianus) nesting habitat using Maximum Entropy and a long-

730 term dataset from Southern Oregon. Ecol. Inform. 3: 375-386.

731 Zeilhofer, P., E. Santos, A. L. M. Ribeiro, R. D. Miyazaki, and M. Santos. 2007. Habitat

732 suitability mapping of Anopheles darlingi in the surroundings of the Manso hydropower plant

733 reservoir, Mato Grosso, Central Brazil. Int. J. Health Geogr. 6: 1-14. 


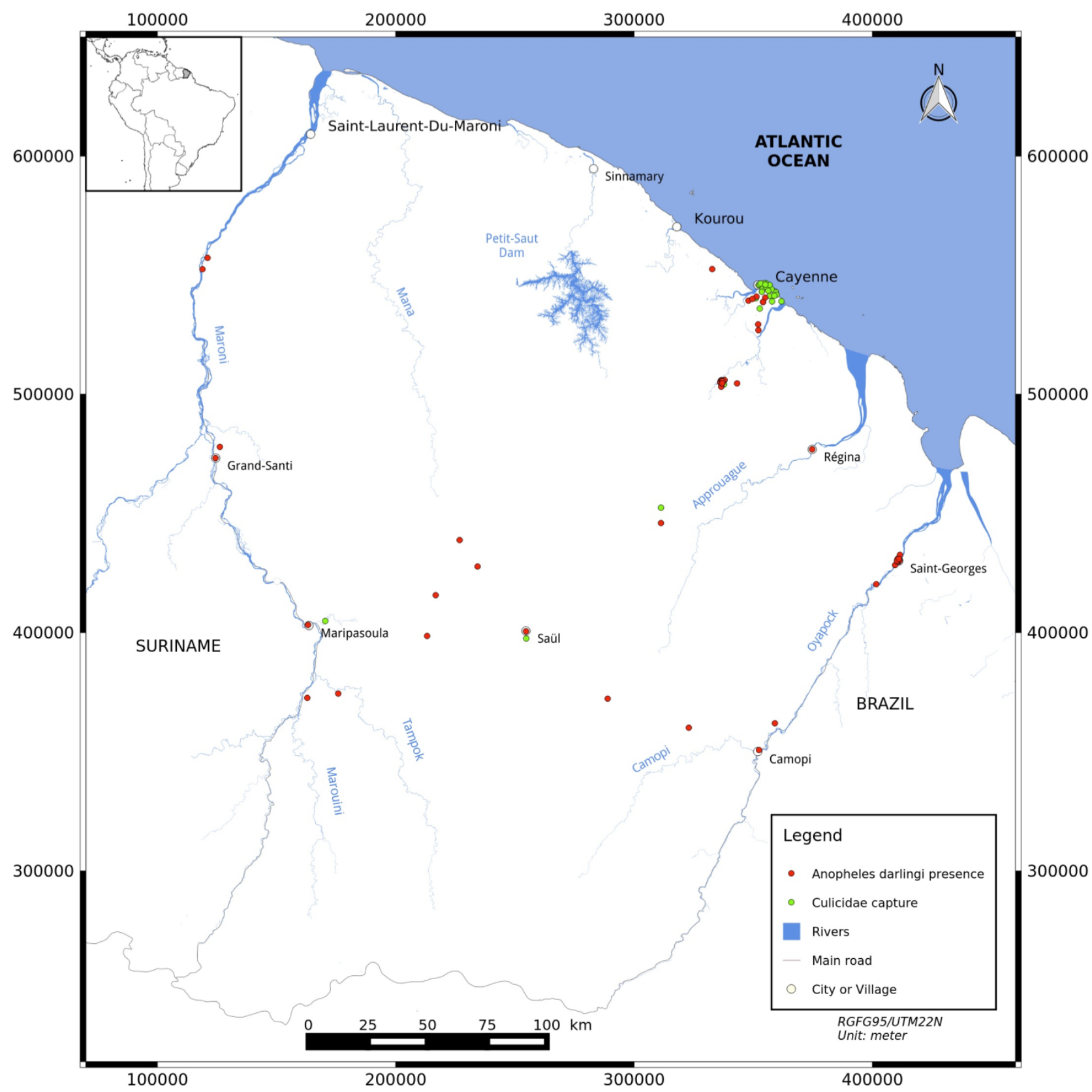

Figure 1. Culicidae capture points and Anopheles darlingi presence points (from 2000 to 2013). 

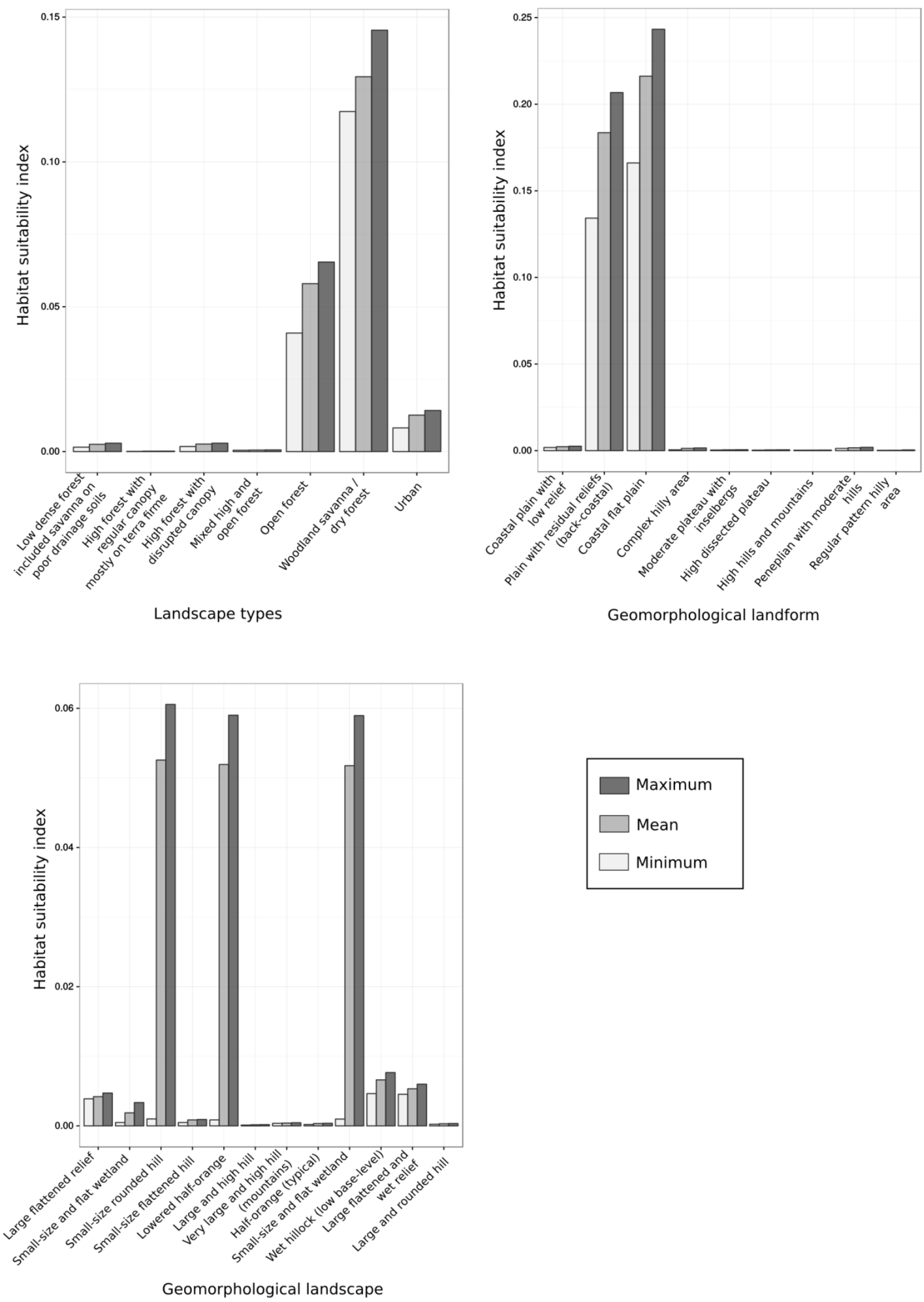

Figure 2. Response curves of categorical environmental variables. 

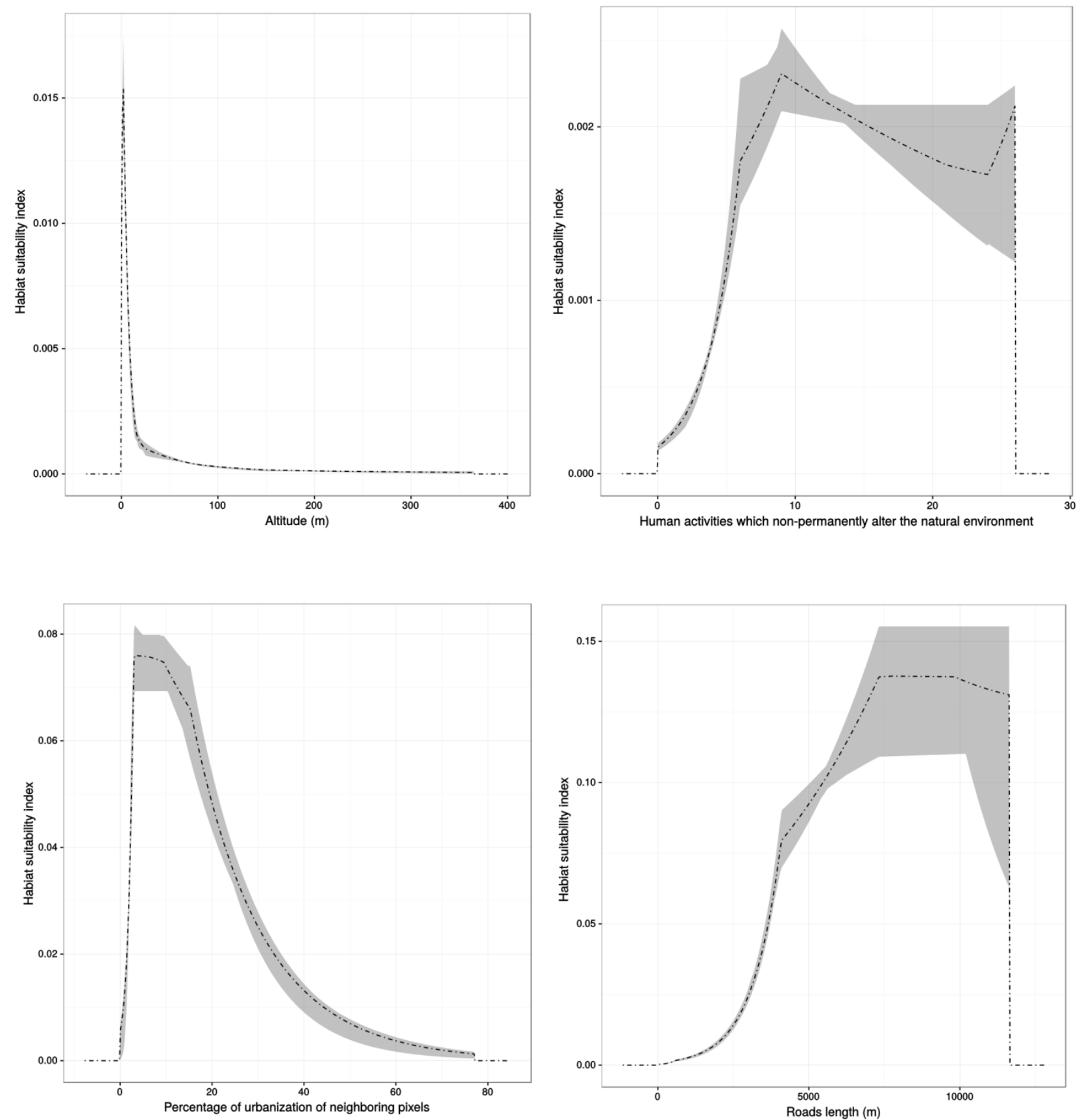

Figure 3. Response curves of numerical environmental variables. Dashed lines show the mean values and the grey regions represent the interval between the maximum and minimum values. 


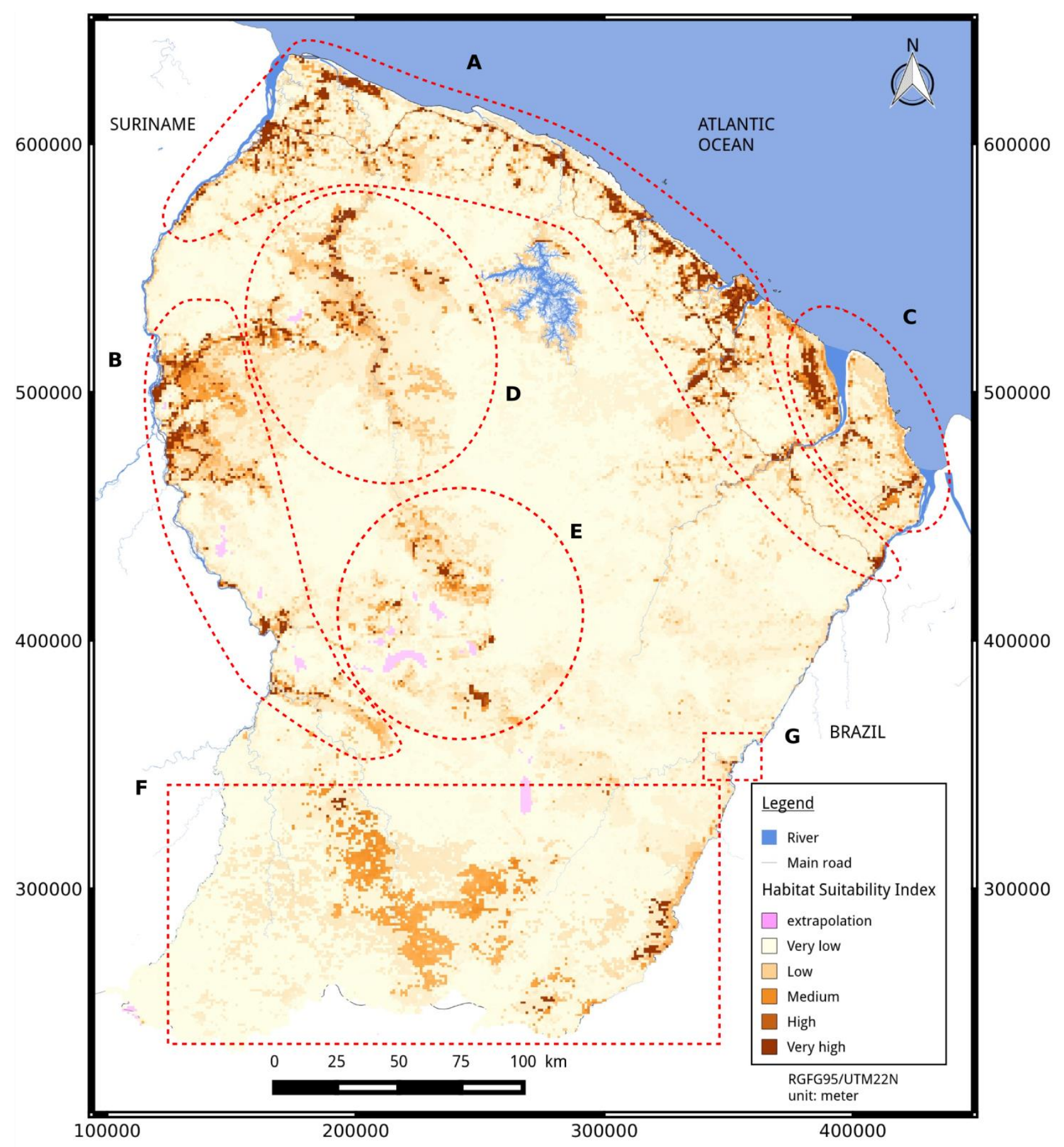

Figure 4. Habitat suitability index map. Six main areas with a high habitat suitability index (A to F) and Camopi village $(\mathrm{G})$ are circumscribed by the red circles and rectangles. 

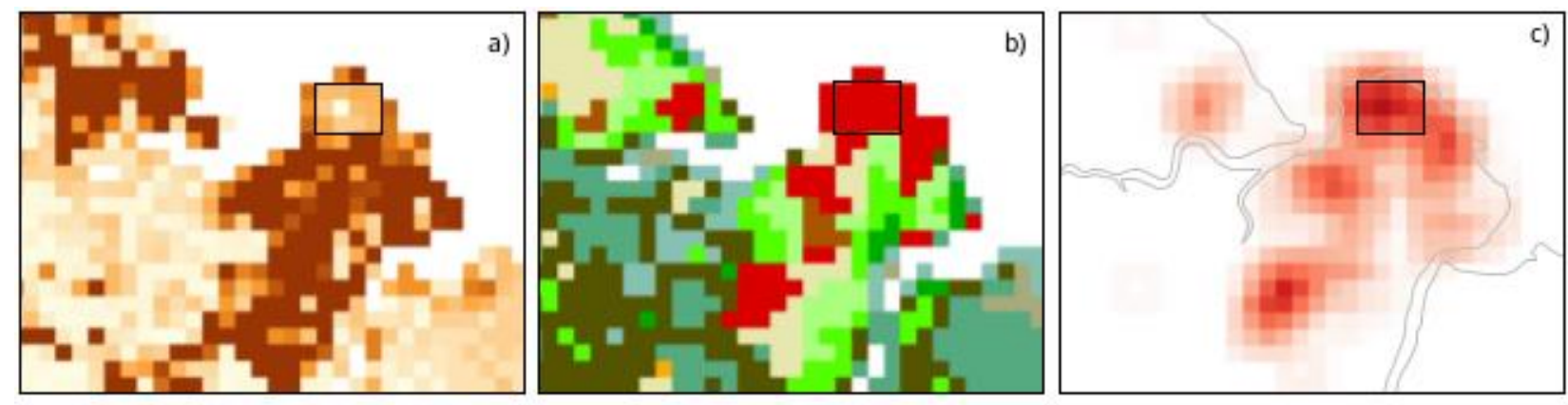

Cayenne
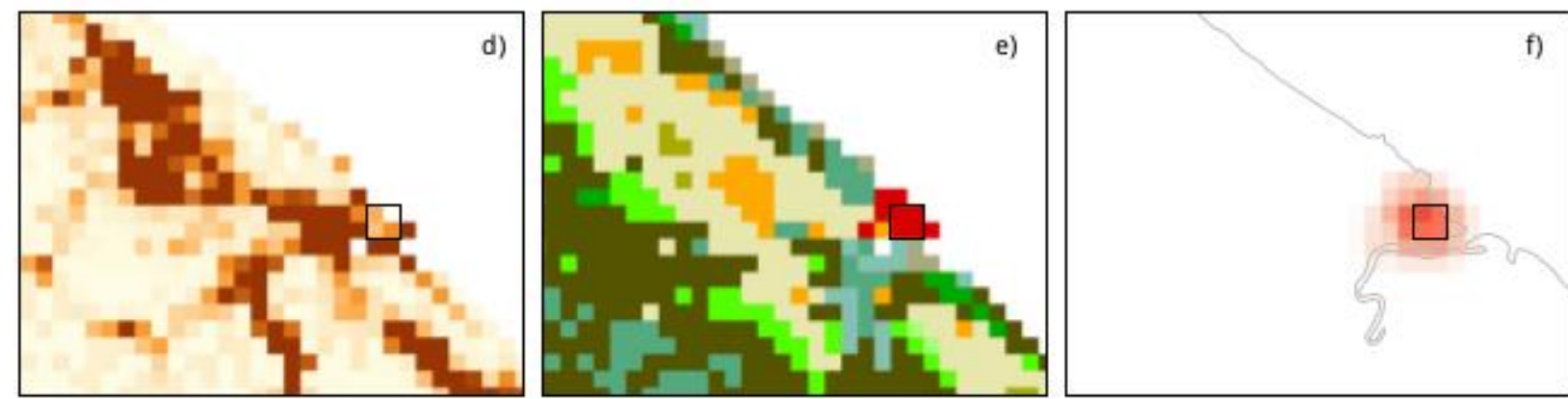

Kourou
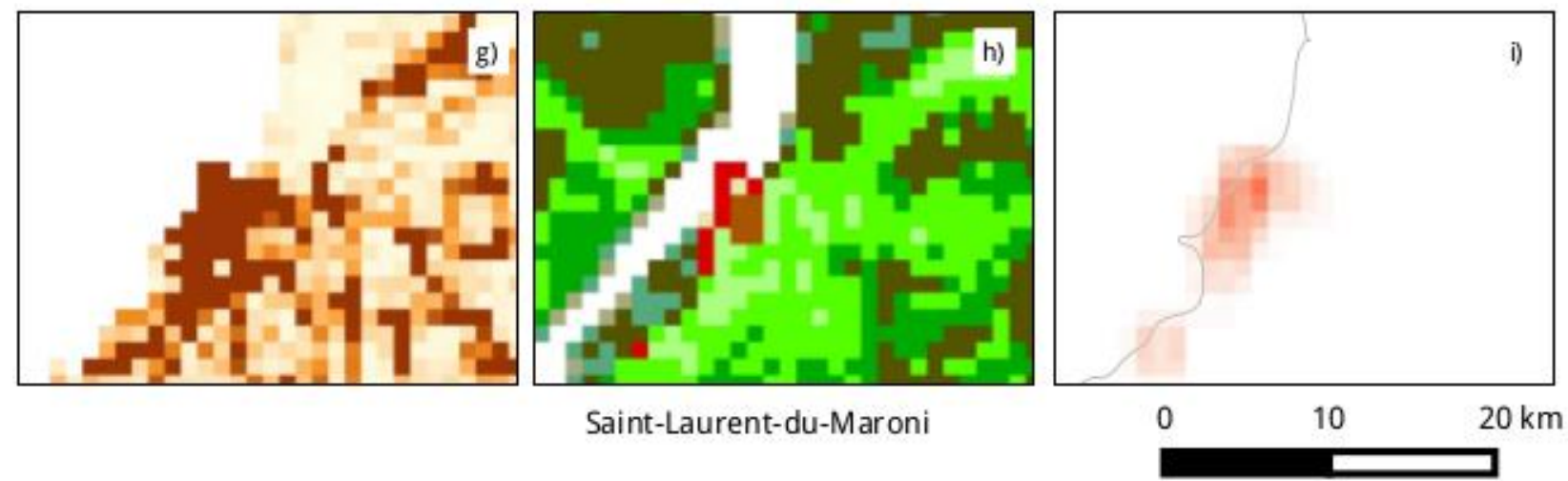

\begin{tabular}{|l|}
\hline Habitat suitability index \\
$\square$ Very High \\
$\square$ High \\
$\square$ Medium \\
$\square$ Low \\
$\square$ Very low \\
\hline
\end{tabular}

Landscape
$\square$ Flooded forest / Montane thicket
Low dense forest / Included savanna on poor drainage soils
High forest with regular canopy mostly on terra firme
High forest with disrupted canopy
$\square$ Mixed high and open forest
$\square$ Open forest
Woodland savanna / Dry forest
Tree / Savanna
$\square$ Grassland / Savanna
Agriculture settlement
$\square$ Mangrove
$\square$ Urban

Urbanization percentage of neighbor pixels

$\square 100$

$\square 75$

$\square 50$

$\square 25$

$\square 0$

Figure 5. Zoom of urban areas. a, d, and g: habitat suitability index maps.

$\mathrm{b}$, e, and h: landscape type. c, f, and i: percentage urbanization of neighbor pixels. Rectangles correspond to highly urbanized areas ( $L S$ class is Urban and PER_URB_NEIGH $\geq 50 \%$ ). Cayenne and Kourou include highly urbanized areas, but Saint-Laurent-du-Maroni does not. 
Moua et al. The habitat suitability of An. darlingi in French Guiana

Table 1. Raw environmental data and derived variables used to build the model.

\begin{tabular}{|c|c|c|c|c|c|c|c|c|c|c|c|}
\hline $\begin{array}{l}\text { Number of } \\
\text { input }\end{array}$ & Producer, reference & $\begin{array}{l}\text { Raw environmental } \\
\text { data }\end{array}$ & $\begin{array}{l}\text { Derived from } \\
\text { (information }\end{array}$ & Date(s) & $\begin{array}{l}\text { Original spatial } \\
\text { resolution or }\end{array}$ & $\begin{array}{l}\text { Derived SDM input } \\
\text { variable(s) }\end{array}$ & $\begin{array}{l}\text { Type of feature } \\
\text { extraction for each }\end{array}$ & $\begin{array}{l}\text { Classes or } \\
\text { range of }\end{array}$ & $\begin{array}{l}\text { Environment } \\
\text { types }^{2}\end{array}$ & $\begin{array}{l}\text { A priori effect on An. } \\
\text { darlingi presence }^{3}\end{array}$ & $\begin{array}{l}\text { Input } \\
\text { variable(s) }\end{array}$ \\
\hline variable & & & source) & & $\begin{array}{l}\text { interpretation } \\
\text { scale }\end{array}$ & & $1 \times 1 \mathrm{~km}$ pixel & $\begin{array}{l}\text { values and } \\
\text { units }\end{array}$ & & $\begin{array}{l}\text { and bibliographic } \\
\text { references }\end{array}$ & type \\
\hline 1 & $\begin{array}{l}\text { Forest National Office } \\
\text { (ONF), (Guitet et al. } \\
\text { 2013) }\end{array}$ & $\begin{array}{l}\text { Geomorphological } \\
\text { landscape }(G L S)\end{array}$ & SRTM & 2000 & $\geq 5000 \mathrm{~m}$ & $\begin{array}{l}\text { Geomorphological } \\
\text { landscape }(G L S)\end{array}$ & Majority class & 12 classes & $\begin{array}{l}\text { Natural } \\
\text { environment }\end{array}$ & $\begin{array}{l}(/) \\
\text { Smith et al. (2013) }\end{array}$ & Categorical \\
\hline 2 & $\begin{array}{l}\text { Forest National Office } \\
\text { (ONF), (Guitet et al. } \\
\text { 2013) }\end{array}$ & $\begin{array}{l}\text { Geomorphological } \\
\text { landform }(G L F)\end{array}$ & SRTM & 2000 & $\geq 200 \mathrm{~m}$ & $\begin{array}{l}\text { Geomorphological } \\
\text { landform }(G L F)\end{array}$ & Majority class & 15 classes & $\begin{array}{l}\text { Natural } \\
\text { environment }\end{array}$ & $\begin{array}{l}(/) \\
\text { Smith et al. (2013) }\end{array}$ & Categorical \\
\hline 3 & $\begin{array}{l}\text { Agricultural Research } \\
\text { Centre for International } \\
\text { Development (CIRAD), } \\
\text { (Gond et al. 2011) }\end{array}$ & Landscape types $(L S)$ & $\begin{array}{l}\text { Spot- } \\
\text { Vegetation }\end{array}$ & 2000 & $1000 \mathrm{~m}$ & Landscape types $(L S)$ & $\begin{array}{l}\text { Correction of pixels } \\
\text { corresponding to } \\
\text { urban areas and } \\
\text { mangroves }\end{array}$ & 14 classes & $\begin{array}{l}\text { Natural } \\
\text { environment } \\
\text { and } \\
\text { urbanization }\end{array}$ & $\begin{array}{l}\text { ( / ) } \\
\text { Stefani et al. (2013) } \\
\text { Girod et al. (2011) } \\
\text { Zeilhofer et al. (2007) } \\
\text { Rozendaal (1992) } \\
\text { Hiwat et al. (2010) } \\
\text { Vittor et al. (2006) } \\
\text { Vittor et al. (2009) }\end{array}$ & Categorical \\
\hline $4,5,6$ & $\begin{array}{l}\text { National Aeronautics } \\
\text { and Space } \\
\text { Administration (NASA) }\end{array}$ & Altitude $(A L T)$ & SRTM & 2000 & $30 \mathrm{~m}$ & $\begin{array}{l}\text { Altitude } \\
\text { - minimum (ALT_MIN), } \\
\text { - maximum (ALT_MAX) } \\
\text { - median (ALT_MED) }\end{array}$ & $\begin{array}{l}\text { Statistical } \\
\text { computation }\end{array}$ & $0-832 \mathrm{~m}$ & $\begin{array}{l}\text { Natural } \\
\text { environment }\end{array}$ & $\begin{array}{l}\text { ( - ) } \\
\text { Zeilhofer et al. (2007) }\end{array}$ & Continuous \\
\hline
\end{tabular}




\begin{tabular}{|c|c|c|c|c|c|c|c|c|c|c|c|}
\hline $\begin{array}{l}\text { Number of } \\
\text { input } \\
\text { variable }\end{array}$ & Producer, reference & $\begin{array}{l}\text { Raw environmental } \\
\text { data }\end{array}$ & $\begin{array}{l}\text { Derived from } \\
\text { (information } \\
\text { source) }\end{array}$ & Date(s) & $\begin{array}{l}\text { Original spatial } \\
\text { resolution or } \\
\text { interpretation } \\
\text { scale }\end{array}$ & $\begin{array}{l}\text { Derived SDM input } \\
\text { variable(s) }\end{array}$ & $\begin{array}{l}\text { Type of feature } \\
\text { extraction for each } \\
1 \times 1 \mathrm{~km} \text { pixel }\end{array}$ & $\begin{array}{l}\text { Classes or } \\
\text { range of } \\
\text { values and } \\
\text { units }\end{array}$ & $\begin{array}{l}\text { Environment } \\
\text { types }^{2}\end{array}$ & $\begin{array}{l}\text { A priori effect on An. } \\
\text { darlingi presence }{ }^{3} \\
\text { and bibliographic } \\
\text { references }\end{array}$ & $\begin{array}{l}\text { Input } \\
\text { variable(s) } \\
\text { type }\end{array}$ \\
\hline 7 & $\begin{array}{l}\text { National Institute of } \\
\text { Geographic and Forestry } \\
\text { Information (IGN) }\end{array}$ & $\begin{array}{l}\text { Road and track } \\
\text { network }\end{array}$ & BD TOPO $®$ & 2011 & $\geq 1000 \mathrm{~m}$ & $\begin{array}{l}\text { Length of roads and tracks } \\
\text { outside of urban areas } \\
(R O A D S)\end{array}$ & $\begin{array}{l}\text { Computation of } \\
\mathrm{road} / \text { track lengths }\end{array}$ & $0-12545 \mathrm{~m}$ & $\begin{array}{l}\text { Non-permanent } \\
\text { anthropogenic } \\
\text { changes }\end{array}$ & $\begin{array}{l}(+) \\
\text { Singer and Castro } \\
(2001)\end{array}$ & Continuous \\
\hline 8 & $\begin{array}{l}\text { Association Kwata } \\
\text { 'Study and Conservation } \\
\text { of French Guianan } \\
\text { Wildlife ' (de Thoisy et } \\
\text { al. 2010) }\end{array}$ & $\begin{array}{l}\text { Human footprint } \\
\text { (HFP) }\end{array}$ & $\begin{array}{l}\text { From various } \\
\text { sources }^{a}\end{array}$ & 2005 & $\geq 1000 \mathrm{~m}$ & $\begin{array}{l}\text { Percentage of urbanization } \\
\text { of neighboring pixels } \\
\left(P E R_{-} U R B \_N E I G H\right)\end{array}$ & $\begin{array}{l}\text { Percentage of } \\
\text { urbanization within } \\
\text { the eight neighbor } \\
\text { cells }\end{array}$ & $0-100 \%$ & Urbanization & $\begin{array}{l}\text { ( - ) } \\
\text { Stefani et al. (2013) }\end{array}$ & Continuous \\
\hline $9,10,11$ & $\begin{array}{l}\text { Association Kwata } \\
\text { 'Study and Conservation } \\
\text { of French Guianan } \\
\text { Wildlife ' (de Thoisy et } \\
\text { al. 2010) }\end{array}$ & $\begin{array}{l}\text { Human footprint } \\
\text { (HFP) }\end{array}$ & $\begin{array}{l}\text { From various } \\
\text { sources }^{a}\end{array}$ & 2005 & $\geq 1000 \mathrm{~m}$ & $\begin{array}{l}\text { Human activities which } \\
\text { non-permanently alter } \\
\text { natural environment }(H A) \\
\text { - minimum (HA_MIN) } \\
\text { - maximum (HA_MAX) } \\
\text { - median (HA_MED) }\end{array}$ & $\begin{array}{l}\text { Statistical } \\
\text { computation }\end{array}$ & $0-30$ & $\begin{array}{l}\text { Non-permanent } \\
\text { anthropogenic } \\
\text { changes }\end{array}$ & $\begin{array}{l}(+) \\
\text { Vittor et al. (2009) }\end{array}$ & Continuous \\
\hline
\end{tabular}

$\overline{{ }^{a}}$ French Institute for Statistical and Economic studies (INSEE); Regional Departments for Food, Agriculture and the Forest (DAAF); ONF; Regional Equipment, Habitat and Planning Authority (DDE) and Hammond et al. (2007).

${ }^{b}$ See the section on environmental variables in Materials and Methods.

${ }^{c}$ A priori effect on An. darlingi presence: (+) favorable; (-) unfavorable; (/) depends on categorical variable values. 
Table 2. Mean contributions and jackknife results of the eleven input environmental variables.

\begin{tabular}{|c|c|c|c|c|}
\hline Environmental variables & Contribution (\%) & Cumulative contribution (\%) & Gain with the variable only & $\begin{array}{l}\text { Decrease of the gain without the } \\
\text { variable }(\%)\end{array}$ \\
\hline$R O A D S$ & 51.45 & 51.45 & 2.20 & -7.98 \\
\hline PER_URB_NEIGH & 17.17 & 68.62 & 1.86 & -0.41 \\
\hline$L S$ & 15.32 & 83.94 & 2.23 & -4.67 \\
\hline \multirow[t]{4}{*}{$H A$} & 7.43 & 91.37 & $\min : 0.02$ & $\min :-0.06$ \\
\hline & (min: 0.35 & & median: 0.15 & median: -0.22 \\
\hline & median: 0.24 & & $\max : 0.43$ & $\max :-2.10$ \\
\hline & $\max : 6.84)$ & & & \\
\hline$G L S$ & 5.35 & 96.72 & 1.40 & -2.59 \\
\hline \multirow[t]{4}{*}{$A L T$} & 2.09 & 98.81 & $\min : 1.12$ & min: - 1.04 \\
\hline & (min: 1.34; & & median: 1.04 & median: -0.39 \\
\hline & median: 0.69 & & $\max : 0.76$ & $\max :-0.03$ \\
\hline & $\max : 0.06)$ & & & \\
\hline$G L F$ & 1.19 & 100 & 0.80 & -0.21 \\
\hline
\end{tabular}


Table 3. Mean contributions and jackknife results of the seven input environmental variables of the simpler model.

Environmental variables Contribution $(\%)$ Cumulative contribution (\%) Gain with the variable only Decrease of the gain without the variable $(\%)$

ROADS 62.61

62.61

2.31 $-8.61$

$L S$ 


\section{Table 4. Characterization of areas with a high HSI}

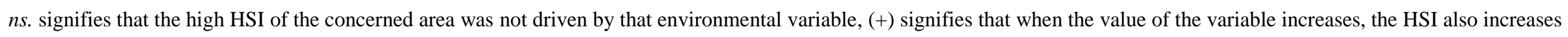
also, (-) signifies that when the value of the variable decreases, the HSI increases, and cells with classes name signifies that the presence of the given class implies a high HSI.

\begin{tabular}{|c|c|c|c|c|c|c|c|}
\hline Area & $R O A D S$ & $L S$ classes & $P E R \_U R B \_N E I G H$ & $H A \_M A X$ & $G L S$ classes & $G L F$ classes & $A L T$ \\
\hline A & $(+)$ & $\begin{array}{l}\text { - Woodland savanna / Dry forest } \\
\text { - Mixed high and open forest }\end{array}$ & $(-)$ & $(+)$ & $\begin{array}{l}\text { - Coastal plain with low relief } \\
\text { - Plain with residual reliefs (back } \\
\text { coastal) }\end{array}$ & $\begin{array}{l}\text { - Small size and flat wetland } \\
\text { - Large flattened and wet relief } \\
\text { - Wet hillock (low base-level) }\end{array}$ & $(-)$ \\
\hline B & $(+)$ & $\begin{array}{l}\text { - Open forest } \\
\text { - Mixed high and open forest }\end{array}$ & $n s$. & $(+)$ & - Peneplain with moderate hills & $\begin{array}{l}\text {-Wet hillock (low base-level) } \\
\text { - Large flattened relief }\end{array}$ & $(-)$ \\
\hline $\mathrm{C}$ & $n s$. & - Open forest & $n s$. & $n s$. & - Coastal flat plain & - Large flattened and wet relief & $(-)$ \\
\hline $\mathrm{D}$ & $(+)$ & - Mixed high and open forest & $n s$. & $(+)$ & $n s$. & $n s$. & $(-)$ \\
\hline $\mathrm{E}$ & $(+)$ & - Mixed high and open forest & $n s$. & $(+)$ & - Peneplain with moderate hills & - Large flattened relief & $(-)$ \\
\hline $\mathrm{F}$ & $n s$. & - Open forest & $n s$. & $n s$. & - Peneplain with moderate hills & - Lowered half-orange & $(-)$ \\
\hline G & $(+)$ & Mixed high and open forest & $n s$. & $(+)$ & $n s$. & $n s$. & $(-)$ \\
\hline
\end{tabular}




\begin{tabular}{|c|c|c|c|}
\hline $\begin{array}{l}\text { Number of } \\
\text { sites }\end{array}$ & Locality & Longitude & Latitude \\
\hline 1 & Cayodé & 175866.785122426 & 374453.1653833 \\
\hline 2 & Taluène & 162884.684665956 & 372648.888139721 \\
\hline 3 & Cacao & 336895.086300153 & 505521.800163598 \\
\hline 4 & Midenangalanti & 121041.015986301 & 557342.72581239 \\
\hline 5 & Grand Santi & 124374.105534813 & 473261.338110987 \\
\hline 6 & Bois Martin & 118927.138507594 & 552587.496776593 \\
\hline 7 & Flavien Campou & 126212.611562883 & 477960.065899793 \\
\hline 8 & Régina & 374698.048396995 & 476928.730177523 \\
\hline 9 & Camopi & 352395.046055802 & 350764.216480451 \\
\hline 10 & Alikéné & 322929.978284572 & 360135.527835386 \\
\hline 11 & Mine Boulanger & 343189.582357019 & 504590.723307373 \\
\hline 12 & Carbet Légion crique Sikini & 359046.553479 & 361996.097871 \\
\hline 13 & Cogneau - 23. Lot. Aquavilla & 354091.053713437 & 538837.801956188 \\
\hline 14 & 41. rue des Ixoras - Lot. Cogneau & 351322.960529913 & 541116.10235073 \\
\hline & Larivot & & \\
\hline 15 & Attila Cabassou & 354987.967015231 & 540678.87835953 \\
\hline 16 & La Chaumière & 347961.540051952 & 539402.864452834 \\
\hline 17 & 1228. Ch. de La Chaumière & 349626.610158034 & 540136.658859129 \\
\hline 18 & Saint-Georges & 411052.118458134 & 429833.606330522 \\
\hline 19 & Quartier Espérance - Saint-Georges & 411113.960068634 & 430709.665437749 \\
\hline 20 & Village Martin - Saint-Georges & 411519.804866871 & 432628.481492214 \\
\hline 21 & Boulangerie - Saül & 254644.262333224 & 400558.641871421 \\
\hline 22 & Chemin Mogès & 352032.329517247 & 529456.717653458 \\
\hline 23 & Dorlin & 216742.863044 & 415732.862195 \\
\hline 24 & Maripasoula & 163199.637191727 & 403271.422431979 \\
\hline 25 & Repentir & 234327.380239 & 427769.677349 \\
\hline
\end{tabular}




\begin{tabular}{|c|c|c|c|}
\hline $\begin{array}{l}\text { Number of } \\
\text { sites }\end{array}$ & Locality & Longitude & Latitude \\
\hline 26 & Stoupan & 352127.057631364 & 527017.037636427 \\
\hline 27 & Camp Pararé - Nouragues & 311267.546406115 & 446010.858172732 \\
\hline 28 & Village Blondin - Saint-Georges & 409492.529993713 & 428392.815435875 \\
\hline 29 & Quartier Adimo - Saint-Georges & 410525.149504269 & 430989.662548913 \\
\hline 30 & Camp Bernet/ Légion étrangère & 410437.343147834 & 429860.701524782 \\
\hline 31 & La ferme de Lait-Quateur & 332757.212761399 & 552628.404024885 \\
\hline 32 & Grand Usine & 288898.531939378 & 372330.073251345 \\
\hline 33 & Dagobert & 226797.35968 & 438864.200286 \\
\hline 34 & Cacao & 336515.199831583 & 505801.969900718 \\
\hline 35 & Saut-Maripa - Camp militaire & 401579.145107468 & 420354.782186144 \\
\hline 36 & Eau-Claire & 213145.824694 & 398626.838699 \\
\hline 37 & Cacao & 336956.199791048 & 504651.969979654 \\
\hline 38 & Cacao & 337909.199733996 & 506008.969874801 \\
\hline 39 & Cacao & 336576.199808207 & 503413.970071365 \\
\hline 40 & Cacao & 336555.199807874 & 503184.970087929 \\
\hline 41 & Impasse de la rafinerie - Cogneau & 354091.053713437 & 538837.801956188 \\
\hline 42 & Quartier Bambou & 411277.041477492 & 430178.275876772 \\
\hline 43 & Quartier Maripa - Saint-Georges & 410252.974346512 & 430188.463058511 \\
\hline 44 & Quartier Savane - Saint-Georges & 411024.737954334 & 430940.054473617 \\
\hline 45 & Cacao & 336826.199809151 & 505764.969900894 \\
\hline 46 & Cacao & 337091.199787723 & 505441.969921949 \\
\hline 47 & Cacao & 336186.199848992 & 505049.969957266 \\
\hline 48 & Quartier Onozo- Saint-Georges & 411339.040785181 & 430641.896115415 \\
\hline
\end{tabular}




\section{S2. Creation of the relative sampling effort map}

Capture data of Culicidae (74 capture sites) were used to estimate the sampling effort of $A n$.

darlingi. The collection methods were identical and the sampling bias for the family was assumed to be representative of that for the focal species.

The sampling bias was defined as the relative sampling effort in the environmental space. For a pixel $i$, it corresponds to the ratio of the number of sampled pixels over the total number of pixels, within the environmental neighborhood of $i$.

First, all pixels of the study area were represented in the environmental variable space. This was accomplished by performing a Factorial Analysis of Mixed Data (FAMD) (Pagès, 2004). This analysis jointly takes into account numerical and categorical variables and makes it possible to represent the pixels within an Euclidean, orthonormal space defined from the whole set of environmental variables.

The membership degree of a pixel $j$ to the neighborhood of pixel $i$, denoted $w_{i j}$, was defined by a Gaussian-like membership function:

$$
w_{i j}=0.5^{\left(d_{i j} / D_{\min }\right)^{2}}
$$

with $d_{i j}$ the euclidean distance between $i$ and $j$ in the factorial space, and $D_{\min }$ the threshold distance over which $j$ does not significantly belong to the environmental neighborhood of $i$, i.e. over which $w_{i j}<0.5$. The membership degree $w_{i j}$ has the following properties:

$$
\begin{aligned}
& \left.\left.-w_{i j} \in\right] 0,1\right] \\
& -w_{i j}=1 \text { if } d_{i j}=0 ; \\
& -w_{i j}<0.5 \text { if } d_{i j}>D_{\min } .
\end{aligned}
$$


The parameter $D_{\min }$ was set from a priori knowledge of An. darlingi bio-ecology. As highly urbanized areas are not suitable for An. darlingi (see $\S$ I.3), we stated that a pixel associated with An. darlingi presence cannot belong to a highly urbanized pixel. Reciprocally, a pixel considered to be highly urbanized cannot belong to the environmental neighborhood of a pixel where An. darlingi was observed.

Consequently, given $P$, the set of pixels where the species was observed and $U$, the set of pixels belonging to highly urbanized areas, $D_{\min }$ was defined as follows:

$$
D_{\min }=\min \left(d_{p u}\right)_{p \in P, u \in U}
$$

A pixel is considered to be highly urbanized if it belongs to the $L C$ class Urban and if its eight neighboring pixels present an average urbanization percentage (PER_URB_NEIGH) higher than or equal to $50 \%$.

The concepts of environmental space and neighborhood, as well as the key method parameters are schematically represented in Figure S1.

Given $X$, the set of pixels of the study area, and $c=\left\{c_{i}\right\}_{i \in X}$, a vector such that $c_{i}=1$ if $i$ is sampled and $c_{i}=0$ otherwise, the relative sampling effort at pixel $i, z_{i}$, is then defined as:

$$
z_{i}=\sum_{j \in X} w_{i j} \cdot c / \sum_{j \in X} w_{i j}
$$

The relative sampling effort was computed for each pixel of the study area. The resulting map was used to bias the random selection of background points. Consequently, for a given pixel, the greater the relative sampling effort, the higher the chance of selecting the pixel as a background point.

\section{Reference}

Pagès, J. 2014. Multiple Factor Analysis by Example Using R. Chapman \& Hall, CRC Press. 


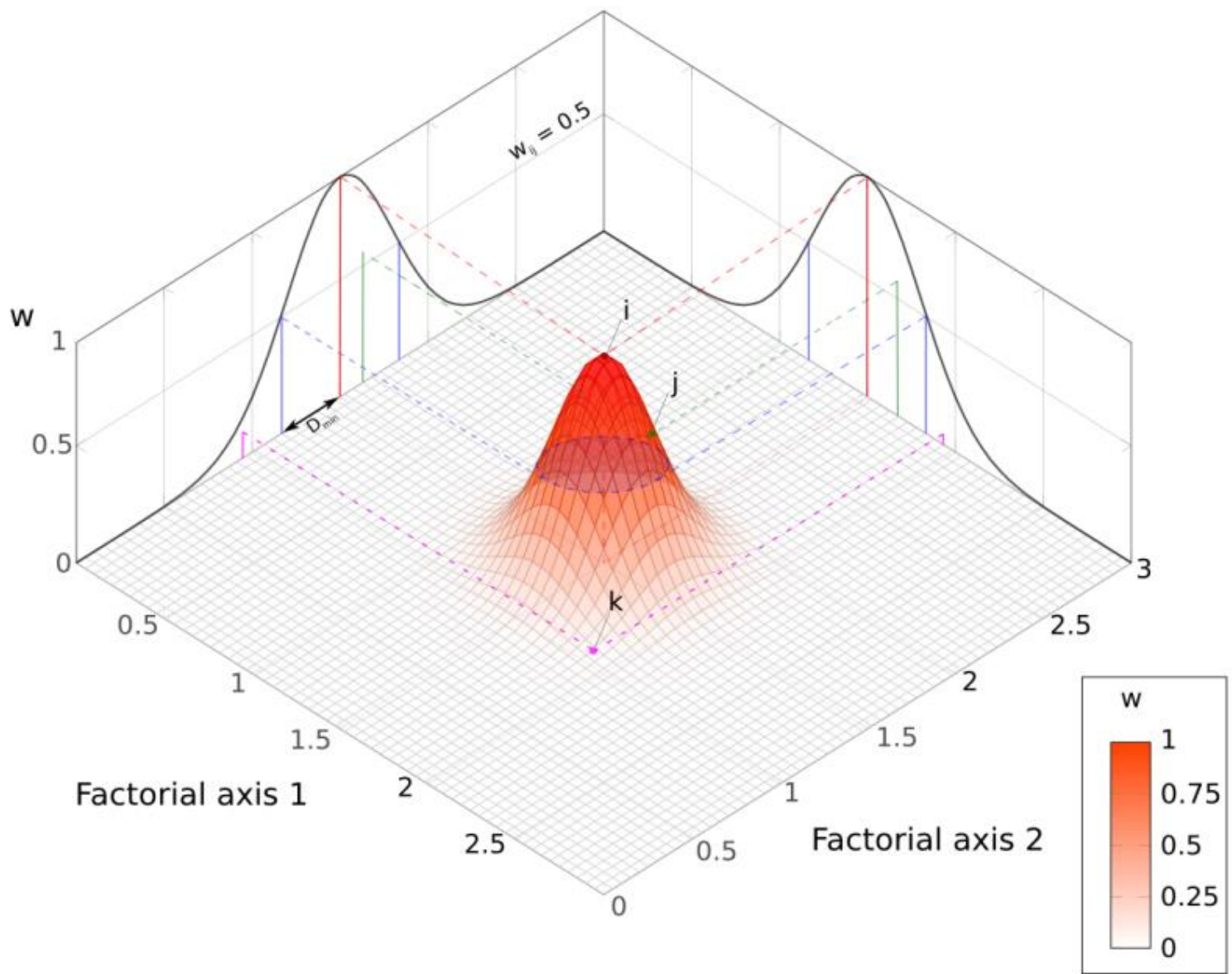

Figure S1. Neighborhood of a pixel $i$ in the environmental space represented by the first and second factorial axes. The environmental neighborhood of point $i$ is represented by the Gaussian function. The blue lines define the limit of the neighborhood of $i$. Only point $j$ is situated above these lines. Thus $j$ is in the neighborhood of $i$ in the first factorial plane. 